Review

\title{
Can Co-Activation of Nrf2 and Neurotrophic Signaling Pathway Slow Alzheimer's Disease?
}

\author{
Kelsey E. Murphy and Joshua J. Park * \\ Department of Neurosciences, College of Medicine and Life Sciences, University of Toledo, Toledo, \\ $\mathrm{OH}$ 43614, USA; kelsey.murphy@rockets.utoledo.edu \\ * Correspondence: joshua.park2@utoledo.edu; Tel.: +1-419-383-4085; Fax: +1-419-383-3008
}

Academic Editor: Katalin Prokai-Tatrai

Received: 25 April 2017; Accepted: 27 May 2017; Published: 31 May 2017

\begin{abstract}
Alzheimer's disease (AD) is a multifaceted disease that is hard to treat by single-modal treatment. AD starts with amyloid peptides, mitochondrial dysfunction, and oxidative stress and later is accompanied with chronic endoplasmic reticulum (ER) stress and autophagy dysfunction, resulting in more complicated pathogenesis. Currently, few treatments can modify the complicated pathogenic progress of $\mathrm{AD}$. Compared to the treatment with exogenous antioxidants, the activation of global antioxidant defense system via Nrf2 looks more promising in attenuating oxidative stress in AD brains. Accompanying the activation of the Nrf2-mediated antioxidant defense system that reduce the $\mathrm{AD}$-causative factor, oxidative stress, it is also necessary to activate the neurotrophic signaling pathway that replaces damaged organelles and molecules with new ones. Thus, the dual actions to activate both the Nrf2 antioxidant system and neurotrophic signaling pathway are expected to provide a better strategy to modify AD pathogenesis. Here, we review the current understanding of AD pathogenesis and neuronal defense systems and discuss a possible way to co-activate the Nrf2 antioxidant system and neurotrophic signaling pathway with the hope of helping to find a better strategy to slow AD.
\end{abstract}

Keywords: Alzheimer's disease; amyloid peptide; mitochondrial damage; oxidative stress; Nrf2; neurotrophic signaling pathway; natural products

\section{Introduction}

Alzheimer's disease (AD) is a devastating neurodegenerative disease that impairs memory, reasoning, and judgment and causes cognitive defect and behavioral changes. AD affects 35.6 million people worldwide and its incidence is expected to increase to 115 million people by 2050. In spite of the upcoming surge of $\mathrm{AD}$ incidence, there is still no disease-modifying treatment for AD.

Removing the AD trigger is thought to be a way to modify AD progress. However, it is still unclear what triggers AD. Moreover, there appears to be more than one trigger, which necessitates multi-modal strategy for AD treatment. Furthermore, new pathogenic factors show up in the middle of $\mathrm{AD}$ pathogenesis, which makes it even harder to control AD. For example, soluble amyloid beta $(\mathrm{A} \beta)$ peptides that are formed at early AD stage initiate multiple vicious cycles that reduce synaptic transmission, damage mitochondria, and increase oxidative stress. Heightened oxidative stress is, then, followed by chronic endoplasmic reticulum (ER) stress response and autophagy dysfunction. The congregation of all those problems makes AD more complicated and untreatable by current therapeutic approaches.

In accord with the complicated pathogenesis of $\mathrm{AD}$, single-modal treatment has been ineffective in controlling AD. Failure of supplemental antioxidants in treating AD is an example of ineffective single-modal treatment. Administered exogenous antioxidants appear to be easily overwhelmed by free reactive radicals that are generated in an unregulated manner due to the loss of endogenous 
antioxidant system. Therefore, a more fundamental solution is required to cope with overwhelming oxidative stress. Activating nuclear factor erythroid 2 (NF-E2)-related factor 2 (Nrf2), the main switch of intracellular antioxidant defense system, may be a reasonable strategy to attenuate oxidative stress globally. That is why researchers have tried to find an effective AD treatment among flavonoids, polyphenols, and compounds that can activate Nrf2 and antioxidant response element (ARE) pathway.

To further modify AD progress, reducing oxidative stress alone may not be sufficient. Regenerative force should be accompanied for repairing damaged mitochondria and rebuilding atrophied neuronal structures. The neurotrophic signaling pathway is the major route used by neurons to regenerate their structures to regain normal synaptic transmission. Therefore, activation of the neurotrophic signaling pathway along with the Nrf2-ARE system should provide a better chance to change the course of AD pathogenesis.

Here, we will briefly review the current understanding of AD-causing factors, key neuronal defense systems, and natural products that activate the defense systems. The most recent literatures that cover each topic relatively well were used as references in our review paper. On the basis of our understanding, we discuss a possible way to modify AD progress by co-activating the Nrf2-ARE and neurotrophic signaling pathway.

\section{AD-Causing Factors}

We summarized the effects of AD-causing factors and their crosstalk in Figure 1.

\subsection{A Peptides}

Accumulated evidence indicates that soluble $A \beta$ peptide oligomers rather than insoluble $A \beta$ peptide fibrils are a major $\mathrm{AD}$-causing factor [1]. Soluble $\mathrm{A} \beta$ peptide oligomers perturb calcium homeostasis by inducing massive calcium influx [2], which leads to the formation of mitochondrial permeability transition pores (mPTPs) in the inner mitochondrial membrane, resulting in depletion of adenosine tri-phosphate (ATP), release of cytochrome c (cyt c) and free radicals, and oxidative stress [3]. $\mathrm{A} \beta$ peptide oligomers also increase tumor necrosis factor $\alpha$ (TNF- $\alpha$ ) and activate the pro-apoptotic kinase, c-Jun N-terminal kinase (JNK), in AD brains [4]. Moreover, A $\beta$ peptide oligomers infuriates microglial cells that, in turn, release free radicals and inflammatory cytokines [5]. All these effects cause oxidative damage to DNA, proteins, and lipids in neurons and eventually their death [6]. In addition to the pro-apoptotic effects, soluble $\mathrm{A} \beta$ peptides acutely inhibit synaptic transmission. High levels of $A \beta$ peptides decrease synapse strength by increasing the endocytosis and degradation of $\alpha$-amino-3-hydroxy-5-methyl-4-isoxazole-propionic acid (AMPA) receptors [7]. A $\beta$ peptides also cause the $N$-methyl-D-aspartate (NMDA)-mediated degradation of postsynaptic density protein 95 (PSD-95) [8]. All these negative effects of $\mathrm{A} \beta$ peptides lead to the reduction of synaptic plasticity and long-term potentiation (LTP) [9], the increase of long-term depression (LTD) [10], and memory deficit [11]. In addition to the above negative effects, soluble $A \beta$ peptides exert other detrimental effects that will be reviewed in later sections.

\subsection{Mitochondrial Dysfunction}

Mitochondrial dysfunction is another major facilitator of AD pathogenesis [12]. It starts as early as 3 months of age in AD mice when intracellular $\mathrm{A} \beta$ peptides become detectable [13]. Mitochondrial dysfunction begins with the uncoupling of mitochondrial electron transport chain (mETC) and the depolarization of mitochondrial membrane potential (MMP), which results in the production of reactive oxygen species (ROS) and the depletion of ATP [14]. Cytochrome c oxidase (COX) in the complex IV of mETC is the most affected ETC enzyme in AD [15]. ETC complex I was also found defective in P301L tau mice, amyloid precursor protein (APP)swe/presenilin 1 (PS1)dE9 mice, Tg4510 $\mathrm{AD}$ mice, and $\mathrm{AD}$ patients [16-18].

$\mathrm{A} \beta$ peptides that directly damage mitochondria are recruited to mitochondria by the translocase of the outer membrane (TOM) machinery [19], receptor for advanced glycation end-products (RAGE) [20], 
and ER-mitochondria cross-contact [21]. After recruitment, $A \beta$ peptides perturb mitochondrial function via its interaction with cyclophilin $\mathrm{D}(\mathrm{CypD})$ [22]. Similarly, the interaction of $A \beta$ peptide with $A \beta$-binding alcohol dehydrogenase $(A B A D)$ also perturbs mitochondrial function [23]. $A \beta$ peptides accumulated inside mitochondria [24] causes the reduction in oxygen consumption and ETC activity [25]. The cortex and hippocampus are the major brain areas where A $\beta$ peptides are accumulated inside mitochondria [26,27].

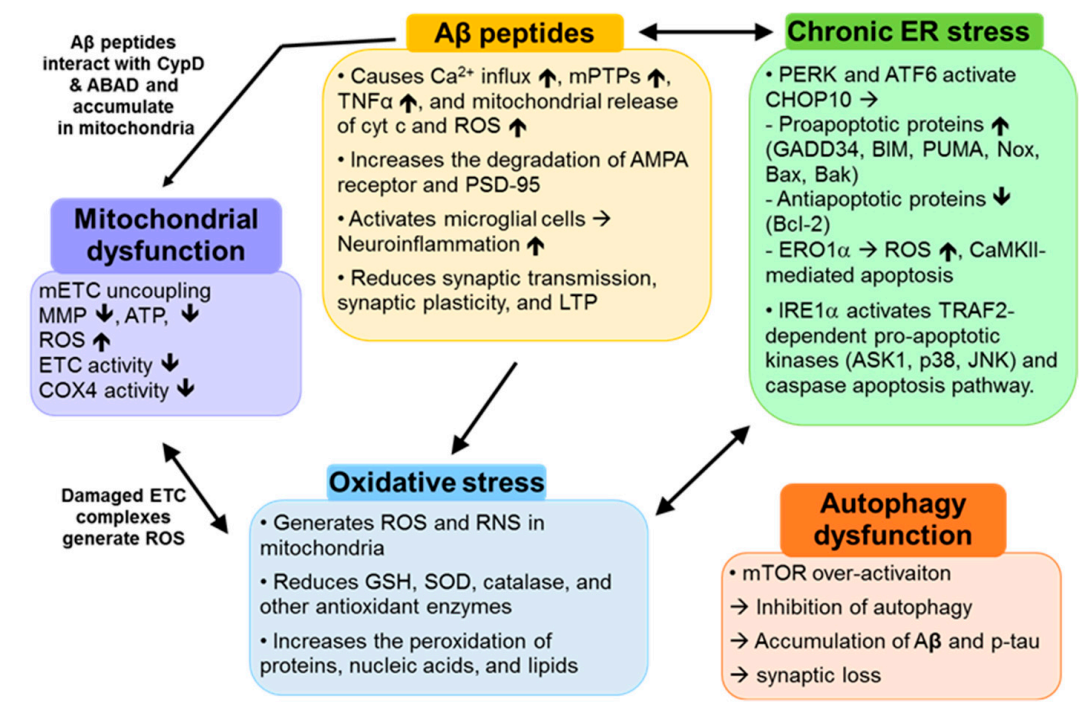

Figure 1. Multifaceted Alzheimer's Disease (AD) pathogenesis. A $\beta$ peptides increase calcium influx, mitochondrial permeability transition pore (mPTP) formation, tumor necrosis factor $\alpha$ $(\mathrm{TNF} \alpha)$, and mitochondrial cytochrome c (cyt c) and reactive oxygen species (ROS) release, reduce $\alpha$-amino-3-hydroxy-5-methyl-4-isoxazole-propionic acid (AMPA) receptor and postsynaptic density protein 95 (PSD95), and activate microglial cells that in turn induce neuroinflammation. All these negative effects lead to the gradual loss of synaptic transmission and plasticity and long-term potentiation (LTP). A $\beta$ peptides directly attack mitochondria via its interactions with cyclophilin D $(\mathrm{CypD})$ and $\mathrm{A} \beta$-binding alcohol dehydrogenase (ABAD), thus causing the uncoupling of mitochondrial electron transport chain (mETC), the reduction of mitochondrial membrane potential (MMP) and adenosine tri-phosphate (ATP), and the loss of ETC enzymes including cytochrome c oxidase 4 (COX4), which result in mitochondrial dysfunction. Damaged mitochondria release ROS and reactive nitrogen species (RNS) which reduce the antioxidant enzymes and increase the peroxidation of intracellular molecules. Both chronic oxidative stress and $A \beta$ peptides are followed by chronic endoplasmic reticulum (ER) stress. During chronic ER stress, protein kinase RNA like ER kinase (PERK) and activating transcription factor 6 (ATF6) activate C/EBP homologous protein-10 (CHOP10) that, in turn, increases pro-apoptotic proteins (growth arrest and DNA damage-inducible protein 34 [GADD34], B-cell lymphoma 2 (BCL-2) interacting mediator of cell death [BIM], p53 upregulated modulator of apoptosis [PUMA], Noxa, Bax, Bak, and ER oxidase $1 \alpha[$ ERO1 $\alpha]$ ) and decreases anti-apoptotic protein, Bcl-2. During chronic ER stress, inositol-requiring kinase $1 \alpha$ (IRE1 $\alpha)$ activates tumor necrosis factor receptor-associated factor 2 (TRAF2)-dependent pro-apoptotic kinases, apoptosis signal-regulating kinase 1(ASK1), p38, and c-Jun N-terminal kinase (JNK) and caspase-mediated apoptosis. Chronic ER stress also contributes to oxidative stress. In AD brains, autophagy becomes dysfunctional due to the over-activation of mammalian target of rapamycin (mTOR). Inhibition of autophagy results in the accumulation of $\mathrm{A} \beta$ peptides and $\mathrm{p}$-tau and the loss of synapses. (black arrows: cause/contribute to).

\subsection{Oxidative Stress}

During aging, endogenous antioxidant capacity is gradually reduced and then overwhelmed by oxidative stress [28]. Loss of antioxidant capacity occurs more quickly in AD brains [28]. For example, the levels of $\mathrm{NAD}(\mathrm{P}) \mathrm{H}$, an ETC electron donor, and glutathione $(\mathrm{GSH})$ were reported to be reduced 
more quickly in the hippocampus and cortex of 3xTg-AD mice than in wild-type mice [29]. Since oxidative stress in general is reviewed elsewhere [30,31], we will only briefly review it here.

During oxidative stress, mitochondrial ETC complexes and cytoplasmic enzymes generate ROS such as superoxide $\left(\mathrm{O}_{2}{ }^{\bullet-}\right)$ and hydrogen peroxide $\left(\mathrm{H}_{2} \mathrm{O}_{2}\right)$ and reactive nitrogen species (RNS) such as nitric oxide $\left({ }^{\bullet} \mathrm{NO}\right)$, dinitrogen tetroxide $\left(\mathrm{N}_{2} \mathrm{O}_{4}\right)$, and peroxynitrite $\left(\mathrm{ONOO}^{-}\right)$[32]. $\mathrm{O}_{2}{ }^{\bullet-}$ is generated mainly by mitochondrial complexes I and III [33]. $\mathrm{O}_{2}{ }^{\bullet-}$ is reduced to $\mathrm{OH}^{\bullet}$ and $\mathrm{OH}^{-} \cdot \mathrm{O}_{2}{ }^{\bullet-}$ and - NO spontaneously react with each other to generate $\mathrm{ONOO}^{-}$. $\mathrm{ONOO}^{-}$is decomposed to generate nitrogen dioxide radical $\left(\mathrm{NO}_{2}{ }_{2}\right)$ and $\bullet^{\bullet} \mathrm{NO}$ [34]. ${ }^{\bullet} \mathrm{NO}$ was reported to impair mitochondrial respiration by inhibiting mitochondrial enzymes including COX [35]. ROS and RNS also cause the peroxidation of proteins, nucleic acids, and lipids, thus inhibiting their normal functions [36-39]. ROS produces carbonyl proteins while RNS causes protein tyrosine nitration (3-nitrotyrosine (3-NT)). High levels of protein carbonylation and 3-NT have been found in the temporal gyri, hippocampus, parietal lobes $[40,41]$ and cerebral cortex [42] in AD patients. Increased ROS is also accompanied with the reduction in the expression and activity of GSH, superoxide dismutase (SOD), and catalase [43,44]. When ROS oxidizes DNA, it generates DNA adducts containing 8-hydroxy-2-deoxyguanine (8-OHdG) that are often found in AD brains [45].

Lipid peroxidation in AD brains occurs mainly by oxidation of polyunsaturated fatty acids in lipid membrane, which produces malondialdehyde (MDA), 4-hydroxy-2-nonenal (4HNE), acrolein, and F2-isoprostanes (F2-IsoPs). The levels of MDA, thiobarbituric acid reactive substances (TBARS), $4 \mathrm{HNE}$, and HNE-modified proteins were found at high levels around neurofibrillary tangles (NFTs) and senile plaques in AD and mild cognitive impairment brains [46,47]. Similarly, acrolein [47] and F2-IsoPs [48] were found at high levels in AD brains.

\subsection{Chronic ER Stress}

Chronic oxidative stress causes the accumulation of unfolded proteins in the ER, which activates ER stress response [49]. During normal ER stress response, glucose-regulated protein 78 (GRP78/Bip) that is saturated with unfolded proteins releases three ER stress sensors, protein kinase RNA like ER kinase (PERK), inositol-requiring kinase $1 \alpha$ (IRE1 $\alpha$ ), and activating transcription factor 6 (ATF6) [50]. Those ER stress sensors increase the expression of ER chaperones, inhibit the entry of proteins into the ER, stop translation, and increase protein export from the ER for degradation [50]. More specifically, PERK phosphorylates the subunit of eukaryotic translation initiation factor $2 \alpha$ (eIF $2 \alpha)$, thus reducing global protein synthesis to prevent further accumulation of unfolded proteins [51]. When ER stress is resolved, phospho-eIF $2 \alpha$ (p-eIF $2 \alpha$ ) is dephosphorylated and inactivated by the phosphatase, growth arrest and DNA damage-inducible protein 34 (GADD34) [52]. Intriguingly, apart from the inhibition of global protein expression, p-eIF $2 \alpha$ increases the expression of ATF4 [53] that induces the expression of proteins associated with redox homeostasis, energy metabolism, and protein folding during ER stress [54].

During ER stress response, IRE1 $\alpha$ mediates the splicing of the mRNA encoding X-box binding protein 1 (XBP-1) into several XBP isoforms that activate the transcription of proteins involved in ER expansion, protein processing, folding, and exporting, and misfolded protein degradation $[55,56]$. IRE $1 \alpha$ also reduces protein synthesis by inducing the degradation of mRNAs using its RNAase activity [57]. Conversely, ATF6 is transported to the Golgi complex during ER stress and cleaved by site- 1 and site- 2 proteases into ATF6 $\alpha$ and ATF6 $\beta$ [58]. ATF6s, in turn, bind to the ER stress response element for the expression of ER chaperones and pro-survival proteins such as GRP94, protein disulfide isomerases (PDIs), XBP-1, and C/EBP homologous protein-10 (CHOP10) [59,60].

In AD brains, ER stress response appears to be chronically activated. The sustained activity of PERK and ATF6 activate CHOP10 [61,62] that, in turn, induces the expression of pro-apoptotic factors such as GADD34, B-cell lymphoma 2 (BCL-2) interacting mediator of cell death (BIM), p53 upregulated modulator of apoptosis (PUMA), and Noxa [63]. CHOP10 also down-regulates Bcl-2 and up-regulates the pro-apoptotic proteins, Bax and Bak [64]. Bax and Bak form oligomeric pores on the mitochondrial outer membrane, thus causing the release of cyt c [65,66], the loss of MMP, and 
the activation of caspase-9 cascade [67]. GADD34 causes the de-phosphorylation of p-eIF2 $\alpha$ [68], which allows excessive protein synthesis and overloads ER with unfolded proteins [69]. CHOP10 also up-regulates ER oxidase $1 \alpha$ (ERO1 $\alpha$ ) that generates excessive ROS and, thus, depletes GSH [70]. ERO1 $\alpha$ also activates ER Inositol-1,4,5-trisphosphate receptor on mitochondria and causes the influx of $\mathrm{Ca}^{2+}$ into mitochondria [71], thus increasing ROS and activating $\mathrm{Ca}^{2+} /$ calmodulin-dependent kinase II (CaMKII)-mediated apoptosis pathway [72]. In addition, chronically activated IRE1 $\alpha$ interacts with tumor necrosis factor receptor-associated factor 2 (TRAF2) and activates pro-apoptotic kinases including apoptosis signal-regulating kinase 1 (ASK1), p38, and JNK [73,74]. TRAF2 also causes the release of pro-caspase-12 that activates caspase-dependent apoptosis [74-76].

Several lines of evidence indicate that chronic ER stress response indeed occurs in AD brains. High levels of ER stress proteins such as GRP78, PERK, p-eIF2 $\alpha$, IRE1 $\alpha, 70-k D a$ heat shock protein (Hsp70), PDI, ATF4, and CHOP10 were found in AD brains [77-80]. Elevated levels of p-eIF2 $\alpha$, ATF4, and protein kinase double-stranded RNA-dependent (PKR) were found to be associated with memory defects [81-83]. It was reported that excessive p-eIF2 $\alpha$ caused cognitive defects [84], increased $\beta$-secretase 1 (BACE1), and promoted amyloidogenesis [85]. Chronic ER stress was also reported to cause tau hyper-phosphorylation in AD brains [86].

\subsection{Autophagy Dysfunction}

Autophagy is activated by the cytoplasmic accumulation of misfolded proteins [87]. Misfolded cytoplasmic proteins are engulfed into multi-membrane vesicles and delivered to lysosomes for degradation [88]. Mammalian target of rapamycin (mTOR) is a main regulator that inhibits autophagy under resting condition [87]. mTOR belongs to two different mTOR complexes, mTOR complex 1 (mTORC1) and mTORC2 [89]. AMP-activated protein kinase (AMPK) [90] and phosphoinositide 3 phosphate kinase (PI3K)/Akt [91] inhibit mTORC1 by phosphorylating mTOR, thus activating autophagy. Autophagy starts with the disassembly of the complex of Unc-51 like kinase 1 (ULK1), autophagy-related protein 13 (ATG13), and focal adhesion kinase (FAK)-family interacting protein 200 (FIP200) [92]. Released ULK1 initiates membrane nucleation by initiating its interaction with PI3KIII, Beclin-1, and ATG6 [93]. Autophagosome membrane is elongated by ubiquitin-like conjugation reactions that are mediated by E1- and E2-like conjugating ATG enzymes [94]. Then, microtubule-associated protein-1A/1B light chain 3 (LC3) is processed to LC3-I that is, in turn, lapidated into LC3-II by ATG complex [95]. LC3-II associates with lipid membrane and mediates the elongation and closure of autophagosomal membrane [96]. In addition, p62 (Sequestosome1) recruit polyubiquitinated proteins to elongating autophagosomes [97].

In AD brains, mTOR is hyperactivated, resulting in the inhibition of autophagy [98], which appears to cause the accumulation of $A \beta$ and p-tau, synaptic loss, and cognitive decline [98]. In line with the speculation of the contribution of hyperactive TOR to AD pathogenesis, inhibition of mTOR can attenuate AD progress. Inhibition of mTOR could restore autophagy $[99,100]$, reduce BACE1 and $A \beta$ peptides [101] and p-tau aggregates [102], and attenuate cognitive deficits [103] in AD brains.

\section{Key Neuronal Defense Systems}

We summarized neuronal defense systems such as antioxidant defense systems and neurotrophic signaling pathways in Figure 2.

\subsection{Antioxidant Defense System}

To fight oxidative stress, neurons need to activate endogenous antioxidant defense system, especially, Nrf2, the main switch for the expression of a majority of endogenous antioxidant enzymes [104-106]. Under resting condition, Nrf2 is sequestered by Kelch-like ECH-associated protein 1 (Keap1) and targeted for rapid ubiquitin-mediated degradation [107]. Upon oxidative stress, Nrf2 is released from microtubule-associated Keap1 after the phosphorylation of Nrf2 and the modification (S-nitrosylation) of Keap1 [108]. Then, p-Nrf2 translocates into the nucleus, dimerizes 
with Maf, and binds to AREs in the promoters of the genes that encodes proteins involved in iron homeostasis (heme oxygenase 1 (HO-1) and Ferritin), redox regulation (catalase, peroxiredoxin (Prx), sulfiredoxin (Srx), thioredoxin (Trx), and SOD), and glutathione synthesis (glutathione S-transferase (GST), glutathione reductase (GR), glutathione peroxidase (GPx), glutathione cysteine ligase regulatory subunit (GCLC), glutathione cysteine ligase modulatory subunit (GCLM), and glutathione synthetase, $\gamma$-glutamyl cysteine sythetase ( $\gamma$-GCS)), quinone recycling (NAD(P)H:quinoneoxidoreductase 1 (NQO1)) [109,110]. p-Nrf2 also up-regulates the expression of the genes involved in mitochondrial biogenesis such as mitochondrial transcription factors (e.g., mitochondrial transcriptional factor $\mathrm{A}$ (TFAM), Nrf1) [111,112].

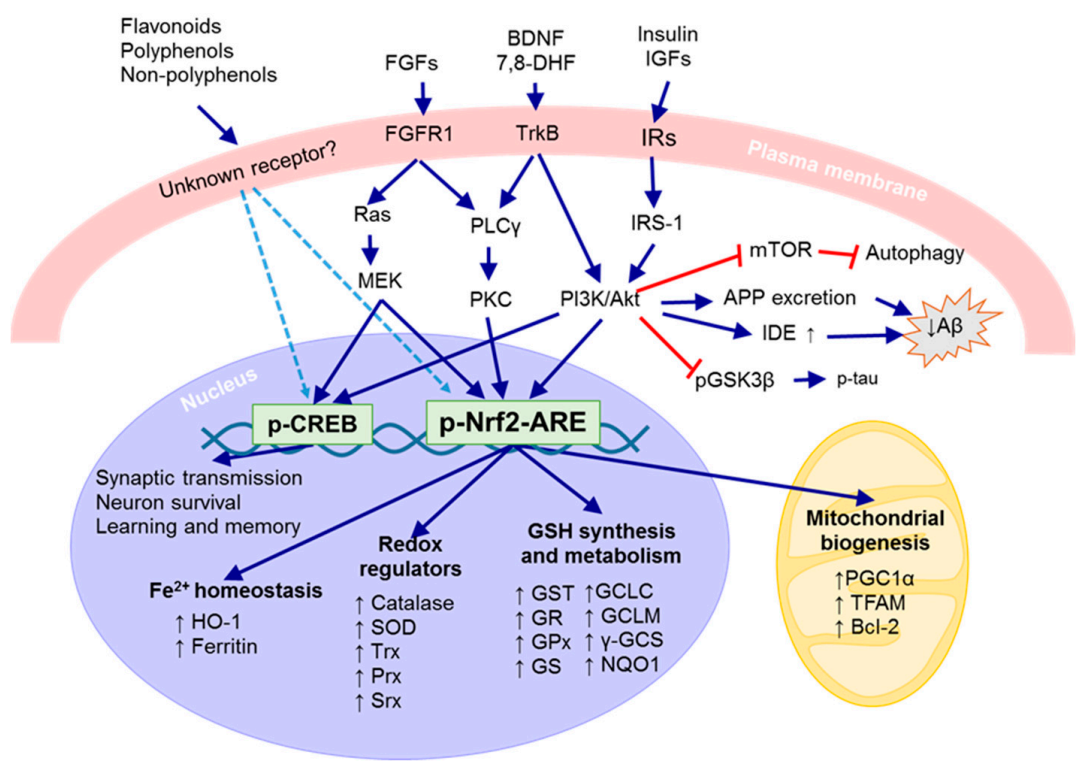

Figure 2. Neuronal defense systems. A group of natural products appear to activate unknown signaling pathways (dotted lines) that lead to the activation of neurotrophic (CREB) and antioxidant (Nrf2-ARE) defense systems in neurons. FGFR1 activated by fibroblast growth factors (FGFs) induces Ras-MEK and PLC $\gamma$-PKC signaling pathways that activate CREB and Nrf2. TrkB activated by brain-derived neurotrophic factor (BDNF) and 7,8-DHF induces PLC $\gamma$-PKC and PI3K-Akt signaling pathways that activate CREB and maybe Nrf2. Insulin receptors (IRs) activated by insulin or IGFs induce IRS-1-PI3K-Akt signaling pathway that activates CREB and maybe Nrf2. Activated Akt inhibits mTOR to activate autophagy, increases APP excretion and IDE expression to reduce A $\beta$ peptides, and inhibits GSK3 $\beta$ to reduce $p$-tau. Activated CREB enhances synaptic transmission, neuron survival, and learning and memory. Activated Nrf2 binds to ARE and increases the expression of antioxidant and detoxifying enzymes involved in $\mathrm{Fe}^{2+}$ homeostasis, redox regulation, and GSH synthesis and metabolism. Activated Nrf2 also enhances mitochondrial biogenesis by increasing the expression of PGC1 $\alpha$, TFAM, Nrf1, and Bcl-2. ( $\uparrow:$ increases; blue arrows: activate/cause; red lines: inhibit; light blue dotted arrows: may activate).

$\mathrm{HO}$ has two isoforms: an inducible enzyme, $\mathrm{HO}-1$, and a constitutive form, $\mathrm{HO}-2$ [113]. A $\beta$ peptide, $\mathrm{H}_{2} \mathrm{O}_{2}$, pro-inflammatory cytokines, and lipopolysaccharide (LPS) can induce the expression of HO-1 [114]. HO-1 showed a strong redox-controlling ability in response to ischemia, ROS, LPS [115], and $A \beta$ peptides [116]. HOs along with nicotinamide adenine dinucleotide phosphate (NADP)H cytochrome $\mathrm{P} 450$ reductase catalyze the degradation of heme groups into equimolar amount of biliverdin, ferrous iron $\left(\mathrm{Fe}^{2+}\right)$, and carbon monoxide (CO) [117]. Biliverdin is converted to the antioxidant bilirubin by biliverdin reductases (BVRs) [118]. Both biliverdin and bilirubin have strong antioxidant and anti-inflammatory effects [119]. There has been some debate about the possible contribution of HO-1 to oxidative stress because HO-1 can generate reactive iron and $\mathrm{CO}$ [120]. 
However, given that HO-1 activity is decreased at early AD stage [121], its contribution to oxidative stress is expected to be insignificant.

SOD mediates the dismutation of $\mathrm{O}_{2}{ }^{\bullet-}$ to $\mathrm{H}_{2} \mathrm{O}_{2}$. There are two SOD isoforms, $\mathrm{Cu} / \mathrm{Zn}-\mathrm{SOD}$ (SOD1) and Mn-SOD (SOD2). SOD1 is present in the cytoplasm, lysosomes, nucleus, and inner membrane mitochondrial space [122] while SOD2 is mostly expressed in mitochondria [123]. SOD2 plays a major role in minimizing the oxidative damage of $\mathrm{O}_{2}{ }^{\bullet-}$ to mitochondria by converting $\mathrm{O}_{2}{ }^{\bullet-}$ to $\mathrm{H}_{2} \mathrm{O}_{2}$ [124]. The deficiency of SOD2 in AD mice further increased $A \beta$ and exacerbated cognitive defect $[125,126]$. Conversely, overexpression of SOD2 reduced ROS production, $\mathrm{A} \beta$ production, memory deficit, and LTP impairment in AD mice [127,128].

Catalase in peroxisomes mediates the conversion of $\mathrm{H}_{2} \mathrm{O}_{2}$ to water and oxygen [129]. Trx and GSH systems detoxicate $\mathrm{ONOO}^{-}$[130]. Trx system consists of Prx, Trx, and thioredoxin reductase (Txnrd) that mediate a series of disulfide exchange reactions to reduce free radicals [131]. GSH system consists of GPx family, glutaredoxin (Grx) family, and GST family [132]. GPx reduces $\mathrm{H}_{2} \mathrm{O}_{2}$ to water. GSH provides an electron to GPx for $\mathrm{H}_{2} \mathrm{O}_{2}$ reduction and then is recycled by GR and NADPH/ $\mathrm{H}^{+}$. GSH is also generated from glutamate, cysteine, and glycine by $\gamma$-GCS, GCL (GCLC + GCLM) and glutathione synthetase (GS). Grx reduces protein disulfides (GSSG) via a disulfide exchange reaction with the expense of GSH to GSSG [132]. GSSG is then reduced back to GSH by GR. GST catalyzes the conjugation of electrophiles, reactive alkenals, xenobiotics to GSH [133].

In AD brains, Nrf2 is primarily located in the cytoplasm and much less in the nucleus [134], suggesting that Nrf2 does not actively induce the expression of antioxidant enzymes in AD brains. In line with this, some Nrf2-dependent antioxidant enzymes such as SOD1 and catalase were found reduced in human AD brains [135]. It was shown that knockout of Nrf2 in APP/presenilin 1 (PS1) mice further increased oxidative damage [136]. On the other hand, overexpression of Nrf2 enhanced neuroprotection against A $\beta$ toxicity and recovered spatial learning in APP/PS1 mice [137]. $18 \alpha$-glycyrrhetinic acid, an Nrf2 activator, enhanced neuron survival against A $\beta$ stress by increasing GCL and GSH [138]. Similarly, triterpenoids that activated Nrf2 attenuated oxidative stress, inflammation, and memory deficit in Tg19959 AD mice [139]. Nrf2 in different physiological and experimental conditions is summarized in Table 1.

Table 1. Summary of the main findings of Nrf2 in physiological and experimental conditions.

\begin{tabular}{|c|c|c|}
\hline Physiological Condition & Nrf2 Action & Reference \\
\hline Resting condition & $\begin{array}{l}\text { - } \quad \text { Mediates the basal expression of antioxidant enzymes } \\
\text { - } \quad \text { Sequestered by Keap1 } \\
\text { - Targeted for ubiquitin-mediated degradation }\end{array}$ & [104-107] \\
\hline Oxidative stress & $\begin{array}{l}\text { - } \quad \text { Phosphorylated } \\
\text { - } \quad \text { Released from microtubule-associated Keap1 following } \\
\text { - } \quad \text { Phe S-nitrosylation of Keap1 } \\
\text { - } \quad \text { Dimerizes with Maf and binds to AREs } \\
\text { - } \quad \text { Upregulates mitochondrial biogenesis genes }\end{array}$ & [108-112] \\
\hline Alzheimer's disease (human brain) & $\begin{array}{l}\text { - } \quad \text { Primarily located in the cytoplasm (less in nucleus) } \\
\text { - } \quad \downarrow \text { Nrf2-mediated expression of antioxidant enzymes }\end{array}$ & {$[134,135]$} \\
\hline Experimental Condition & Outcome & Reference \\
\hline Nrf2 knockout (APP/PS1 mice) & $\uparrow$ Oxidative damage & [136] \\
\hline Nrf2 overexpression (APP/PS1 mice) & $\begin{array}{l}\uparrow \text { Neuroprotection against } \mathrm{A} \beta \text { toxicity } \\
\uparrow \text { Spatial learning and memory }\end{array}$ & [137] \\
\hline $\begin{array}{l}\text { Nrf2 activation via } 18 \alpha \text {-glycyrrhetinic } \\
\text { acid ( } 3 \times \text { Tg-AD neurons) }\end{array}$ & $\begin{array}{l}\uparrow \text { Neuron survival against } A \beta \text { stress } \\
\uparrow \text { GCL and GSH }\end{array}$ & [138] \\
\hline $\begin{array}{l}\text { Nrf2 activation via triterpenoids } \\
\text { (Tg19959 AD mice) }\end{array}$ & $\downarrow$ Oxidative stress, inflammation, memory deficit & [139] \\
\hline
\end{tabular}


Taken together, all these facts point to that the activation of the Nrf2-ARE antioxidant system could be the way to reduce global oxidative stress and its related pathogenesis in AD brains. As such, people have searched for exogenous compounds for the global activation of the Nrf2-ARE defense system [140-143].

\subsection{Neurotrophic Defense System}

In addition to antioxidant defense system, neurons use neurotrophic signaling pathways to survive neurodegenerative condition. cAMP response element binding protein (CREB) is a major transcription factor in neurotrophic signaling pathways $[144,145]$. Upon activation by phosphorylation, phospho-CREB ( $p$-CREB) enters the nucleus and induces the expression of proteins required for neuron survival [146] and synaptic transmission [144,145]. Extracellular signal-regulated kinase (ERK) is another activator of neuron survival signaling pathway $[147,148]$. Upon phosphorylation, p-ERK enters the nucleus and activates transcription factors including CREB required for neuroprotection [149]. The following protein growth factors are the major activators of the neurotrophic signaling pathways for neuron survival.

\subsubsection{Brain-Derived Neurotrophic Factor (BDNF)}

BDNF is the primary neurotrophic growth factor that enhances synaptic plasticity and memory in adult brain $[150,151]$ by activating tropomyosin-related kinase B (TrkB) receptor [152]. Activation of TrkB leads to the activation of PI3K/Akt, phospholipase- $\gamma$ (PLC- $\gamma$ ), ERK [153], and CREB [154]. BDNF was shown to protect adult CA1 hippocampal neurons from traumatic and ischemic brain injuries [155,156] and glutamate toxicity [157], and enhance the survival of basal forebrain cholinergic neurons [158]. However, the expression of BDNF was significantly decreased in AD patients $[159,160]$ and AD animals [161,162]. There have been various efforts to deliver BDNF into AD brains while their efficacy has been limited by the poor blood brain barrier (BBB)-permeability and short half-life of BDNF [163].

\subsubsection{Insulin and Insulin-Like Growth Factor (IGF)}

Insulin was shown to enhance synapse formation and neuron survival [164,165] and improve learning and memory [166] and cognitive function [167]. IGF showed similar effects to insulin [168]. Insulin, IGFs, and their receptors are expressed in neurons [169] and in the olfactory bulb, hypothalamus, cerebral cortex, cerebellum and hippocampus [168,170]. Activation of insulin receptor (IR) by either insulin or IRS-1 leads to the autophosphorylation of IR [168,170]. p-IR phosphorylates insulin receptor substrate (IRS) [170] that, in turn, activates PI3K-Akt [171]. Activated PI3K-Akt enhanced synaptic plasticity and memory consolidation [172], protected mitochondria [173], and reduced mitochondrial dysfunction and free radical production [174]. Activated PI3K-Akt also reduced $A \beta$ peptides by increasing the expression of insulin-degrading enzyme (IDE) that degrades $A \beta$ peptide $[175,176]$ and the excretion of APP [177]. In addition, activated PI3K-Akt reduced p-tau production by inhibiting glutathione synthase kinase $3 \beta$ (GSK3 $\beta$ ) that generates p-tau [178]. Since insulin has a good BBB-permeability, it has been administered to AD patients via intranasal administration [179]. Insulin shows some efficacy in improving memory and cognition in early AD patients $[180,181]$.

\subsubsection{Fibroblast Growth Factors (FGFs)}

FGF2 was shown to activate CREB via mitogen-activated protein kinase (MAPK) and PI3K/Akt, thus enhancing neuron survival [182]. FGF2 up-regulated BDNF-TrkB-ERK-CREB signaling in retinal ganglion cells [183] and in olfactory receptor neural precursor cells [184]. Interestingly, FGFs are also able to enhance endogenous antioxidant system. FGF1 increased the expression of HO-1 and other antioxidant enzyme proteins in rat spinal cord astrocytes by activating Nrf2 [185]. FGF9 induced MAPK/ERK kinase (MEK)-ERK and PI3K-Akt signaling pathways to activate CREB and Nrf2 and 
increased $\gamma$-GCS and HO-1 [186,187]. Klotho, an activator of FGF23-FGF receptor signaling pathway, induced PI3K-Akt signaling pathway and increased Trx/Prx antioxidant system, thus protecting cells from glutamate-toxicity and oligomeric $A \beta$ peptides in hippocampal neurons [188]. In spite of the beneficial effects of FGFs, the mitogenic effect of FGFs via the interaction of FGF receptor with neural cell adhesion molecule 1 (NCAM1) has been a problem for their clinical application [189]. Recently, flbroblast growth loop (FGL) peptide that activates only FGF receptor but not NCAM1 arose as a good alternative to FGFs [189].

\section{Natural Compounds That Can Activate Nrf2 and/or Neurotrophic Signaling Pathway}

In this section, we will briefly review natural compounds that were reported to activate the Nrf2 antioxidant system and/or neurotrophic signaling pathway. We do not cover all Nrf2-activating compounds in this review since many of those are covered by others [105,190]. The targets, outcomes, and research models for the preclinical studies using these natural compounds are summarized in Table 2.

\subsection{Flavonoids}

Flavonoids usually activate the Nrf2-ARE antioxidant system for their neuroprotective actions. Pinocembrin, an herb flavonoid, that showed neuroprotective effects in cerebral ischemic injury [191], glutamate toxicity [192], APPsw-overexpressing SH-SY5Y cells [193], and vascular dementia animal $[194,195]$ appears to use the Nrf2-ARE system for its neuroprotective action [196]. Pinocembrain increased nuclear Nrf2 and activated the ARE-mediated expression of HO- 1 and $\lambda$-GCS in SH-SY5Y cells, thus protecting the cells from 6-hydroxydopamine (6-OHDA)-induced oxidative stress [196]. Naringenin, a grapefruit flavonoid, that showed neuroprotective effects in Parkinson's disease and AD models [197,198] increased nuclear Nrf2 and HO-1, GCLC, GCLM, and GSH in SH-SY5Y cells and inside mouse brain and, thus, exerted neuroprotection [199]. Genistein, an isoflavonoid, that showed a neuroprotective effect in global cerebral ischemia (GCI) cell models [200,201] and animal models [202] activated Nrf2-ARE signaling, increased HO-1, reduced 8-OHdG and 4HNE in hippocampal CA1 neurons, and improved learning and memory [202]. Genistein also induced the endothelial nitric oxide synthase (eNOS)-mediated S-nitrosylation of Keap1, thus releasing Nrf2 from Keap1 for the nuclear accumulation of Nrf2 in hippocampal CA1 neurons [202]. Orientin, a flavone, was shown to activate Nrf2, increase HO-1 and ARE signaling, reduce the levels of ROS, 3-NT, 4HNE, and 8-OHdG, and attenuate $A \beta 1-42$ peptide-induced mitochondrial dysfunction and apoptotic pathway and cognitive defects in AD mice [203]. Eriodictyol, a Chinese herb flavonoid, was reported to activate the Nrf2-ARE system, increase HO-1, GCLC, and GCLM, and reduce ROS and apoptosis in A $\beta$ peptide-exposed cortical neurons [204].

There are a group of flavonoids that can activate both antioxidant defense system and neurotrophic signaling pathway. Luteolin that exerted neuroprotection against $\mathrm{H}_{2} \mathrm{O}_{2}$ [205], $\mathrm{A} \beta$ peptide [206], and serum-starvation [207] was shown to activate both Nrf2-ARE signaling and neurotrophic signaling pathways in PC12 cells [207]. In PC12 cells, luteolin induced neurite outgrowth and increased the expression of growth-associated protein 43 (GAP-43) and HO-1 and the ARE-binding of Nrf2 in an ERK/PKC-dependent manner [207]. Apigenin, a plant flavone, suppressed oxidative stress in hippocampal neurons [208] and restored ERK-CREB signaling pathway in APP/PS1 AD mice [209]. Apigenin suppressed ROS elevation and reversed GSH depletion in kainic acid-treated hippocampal neurons in vitro and in the CA3 region of kainic acid-treated mice [208]. In APP/PS1 AD mice, apigenin attenuated deficits in learning and memory, reduced $A \beta$ peptide production, increased the activity of SOD and GPx, and restored ERK/CREB/BDNF-mediated signaling pathway [209]. Lastly, 7,8-dihydroxyflavone (7,8-DHF) that showed neuroprotective effects in Fragile X mental-retardation gene (fmr1) knockout mice [210] and Tg2576 AD mice [211] has both neurotrophic and antioxidant effects as described by Moosavi et al. [190]. 7,8-DHF can induce TrkB dimerization and phosphorylation 
and activate PI3K-Akt-ERK/CREB signaling pathway, thus enhancing neuron survival in hippocampal, motor, and ganglionic neurons $[190,212]$.

\subsection{Non-Flavonoid Polyphenols}

Compared to flavonoid polyphenols, non-flavonoid polyphenols appear to lean toward neurotrophic signaling pathway for their neuroprotective actions. Curcumin that showed neuroprotective effects against $A \beta$ peptide [213] and in AD animal models [214] was reported to activate CREB-ERK signaling pathway in A $\beta 1-42$-injected rats [215] and insulin signaling in 3xTg-AD mice [4]. In A $\beta$-injected rats, curcumin increased BDNF and p-ERK in the hippocampi and improved cognitive behavior in an ERK-dependent manner [215]. In 3xTg-AD mice that were feed with high fat diet (HFD) [4], curcumin reduced the HFD-induced activation of JNK and the inhibitory phosphorylation of IRS-1 (that allows PI3K/Akt activation) and ameliorated memory deficit [4]. Interestingly, $\mathrm{O}$-demethylcurcumin, a curcumin chemical analog that has a similar neuroprotective effect to curcumin, not only attenuated $A \beta$ peptide-induced caspase-dependent apoptosis but also reduced the expression of ER stress proteins such as p-PERK, p-eIF2 $\alpha, \mathrm{p}$-IRE1 $\alpha, \mathrm{XBP}-1, \mathrm{ATF} 6$, and CHOP in SK-N-SH cells [216]. It suggests that neurotrophic treatment may control ER stress response. Topiramate that showed neuroprotection from focal cerebral ischemia [217] and epileptic hippocampal injury [218] protected hippocampal neurons from glutamate-mediated excitotoxicity by up-regulating BDNF, p-TrkB, p-ERK, and p-CREB [219]. Compared to other non-flavonoid polysaccharides, Harpagoside, an iridoid glycoside polyphenol, can activate both antioxidant defense systems [220] and PI3K-Akt-ERK signaling system [221]. Harpagoside decreased lipid peroxidation and increased the activity of GR and SOD and the level of GSH in the cortex and hippocampus of scopolamine (muscarinic antagonist)-treated mice [220]. In other study, harpagoside treatment increased BDNF, activated ERK and TrkB-PI3K-Akt signaling pathway, and reduced memory defect in $A \beta$ peptide-treated rats [221]. In $A \beta$ peptide-treated cortical neurons, harpagoside decreased neurite atrophy and apoptosis in a TrkB-dependent manner [221].

\subsection{Non-Polyphenol Compounds}

Some non-polyphenol compounds also appear to use antioxidant system and neurotrophic signaling pathway for their neuroprotective actions. Taurine, a mammalian amino acid, was shown to protect neurons from glutamate cytotoxicity, maintain MMP, and reduce ROS in SH-SY5Y cells [222]. Taurine also protected mitochondria by activating Akt-CREB-peroxisome proliferator-activated receptor gamma co-activator 1- $\alpha$ (PGC1 $\alpha$ ) pathway [223-225]. In prenatally-stressed (PS) rats that had defects in learning and memory, taurine reduced mitochondrial ROS, restored MMP, COX, ATP, and SOD2, and increased Akt-CREB signaling pathway and PGC1 $\alpha$ expression in the hippocampi [223]. Given that PGC1 $\alpha$ is a mitochondrial activator that upregulates the transcription of proteins (e.g., TFAM) required for mitochondrial biogenesis and respiratory function [226], taurine appears to use PGC1 $\alpha$ to restore mitochondrial function in the brains of PS rats. $R$ - $\alpha$-lipoic acid, a cofactor for pyruvate dehydrogenase and $\alpha$-ketoglutarate dehydrogenase, was reported to enhance the syntheses of GSH and vitamin E [227] and activate both Akt/PI3K and Nrf2-ARE signaling pathways [228]. In retinal neuronal RGC-5 cells, $R$ - $\alpha$-lipoic acid increased the expression of HO-1 by inducing the nuclear translocation of $\mathrm{Nrf2}$ in a PI3K-dependent manner [228]. $R$ - $\alpha$-lipoic acid also reduced ROS, $4 \mathrm{HNE}$, and cell death inside animal [228]. Allicin, a garlic ingredient, was reported to reduce A $\beta$-induced memory deficit [229] and activated Nrf2 [230]. Allicin attenuated tau hyperphosphorylation, ROS generation, lipid peroxidation, protein carbonylation, antioxidant enzyme reduction, PERK activation, and cognitive defect in vivo [230]. 
Table 2. Natural compounds that activate Nrf2-ARE and/or neurotrophic PI3K-Akt signaling pathways.

\begin{tabular}{|c|c|c|c|c|}
\hline Activator & Target & Outcome & Research Model & Reference \\
\hline \multicolumn{5}{|l|}{ Flavonoids } \\
\hline Pinocembrin & Nrf2-ARE & $\begin{array}{l}\uparrow \text { Nuclear Nrf2, HO-1 and } \lambda \text {-GCS activation } \\
\uparrow \text { Protection from 6-OHDA-induced oxidative stress }\end{array}$ & SH-SY5Y cells & [196] \\
\hline Naringenin & Nrf2-ARE & $\uparrow$ Nuclear Nrf2 and HO-1, GCLC, GCLM, GSH & SH-SY5Y cells, C57BL/6 mouse & [199] \\
\hline Genistein & Nrf2-ARE & $\begin{array}{l}\uparrow \text { HO-1, learning and memory, } \\
\downarrow 8 \text {-OHdG, 4HNE } \\
\uparrow \text { eNOS-mediated S-nitrosylation of Keap1 } \\
\uparrow \text { Nuclear Nrf2 }\end{array}$ & GCI rat hippocampal CA1 neurons & [202] \\
\hline Orientin & Nrf2-ARE & $\begin{array}{l}\uparrow \mathrm{HO}-1 \\
\downarrow \text { ROS, 3-NT, } 4 \mathrm{HNE} \text {, and 8-OHdG, mitochondrial dysfunction, } \\
\text { apoptosis, cognitive defects }\end{array}$ & AD mice & [203] \\
\hline Eriodictyol & Nrf2-ARE & $\begin{array}{l}\uparrow \text { HO-1, GCLC, GCLM } \\
\downarrow \text { ROS and apoptosis }\end{array}$ & $\mathrm{A} \beta$ peptide- exposed cortical neurons & {$[204]$} \\
\hline Luteolin * & Nrf2-ARE and neurotrophic & $\uparrow$ Neurite outgrowth, GAP-43, HO-1, ARE-binding of Nrf2 & PC12 cells & [207] \\
\hline Apigenin * & $\begin{array}{l}\text { Antioxidant and } \\
\text { PI3K-Akt-ERK/CREB }\end{array}$ & $\begin{array}{l}\downarrow \text { Excitotoxicity, ROS, } \uparrow \text { GSH } \\
\uparrow \text { SOD and GPx, learning and memory } \\
\downarrow \text { A } \beta \text { peptide production and deposition }\end{array}$ & $\begin{array}{l}\text { kainic acid-treated neurons and mice } \\
\text { APP/PS1 AD mice }\end{array}$ & {$[208,209]$} \\
\hline $7,8-\mathrm{DHF}^{*}$ & $\begin{array}{l}\text { Antioxidant and } \\
\text { PI3K-Akt-ERK/CREB }\end{array}$ & $\uparrow$ TrkB dimerization and phosphorylation, neuron survival & $\begin{array}{l}\text { hippocampal, motor, } \\
\text { ganglionic neurons }\end{array}$ & {$[190,212]$} \\
\hline \multicolumn{5}{|c|}{ Non-Flavonoid Polyphenols } \\
\hline Curcumin & PI3K-Akt/CREB-ERK/insulin & $\begin{array}{l}\uparrow \text { BDNF, pERK, improved cognitive behavior } \\
\downarrow \text { Active JNK, inhibitory IRS-1 phosphorylation, memory deficit }\end{array}$ & $\begin{array}{l}\text { A } \beta \text {-injected rats (hippocampus) } \\
\text { 3xTg-AD mice on HFD }\end{array}$ & {$[4,215]$} \\
\hline O-Demethylcurcumin & $\begin{array}{l}\text { Neurotrophic/ER stress } \\
\text { response }\end{array}$ & $\begin{array}{l}\downarrow \text { A } \beta \text {-induced caspase-dependent apoptosis } \\
\downarrow \text { ER stress protein expression (p-PERK, p-eIF } 2 \alpha, \text { p-IRE1 } \alpha, \\
\text { XBP-1, ATF6, and CHOP) }\end{array}$ & SK-N-SH cells & [216] \\
\hline Topiramate & Neurotrophic & $\begin{array}{l}\downarrow \text { Glutamate-mediated excitotoxicity } \\
\uparrow \text { BDNF, p-TrkB, p-ERK, p-CREB }\end{array}$ & hippocampal neurons & [219] \\
\hline Harpagoside * & $\begin{array}{l}\text { Antioxidant and } \\
\text { PI3K-Akt-ERK }\end{array}$ & $\begin{array}{l}\uparrow \text { GR, SOD, GSH } \\
\downarrow \text { Lipid peroxidation, memory deficit } \\
\uparrow \text { BDNF, } \downarrow \text { memory defect } \\
\downarrow \text { Neurite atrophy and apoptosis }\end{array}$ & $\begin{array}{l}\text { cortex and hippocampus in } \\
\text { scopolamine- treated mice } \\
\text { A } \beta \text { peptide- treated rats, } A \beta \text { peptide- } \\
\text { treated cortical neurons }\end{array}$ & {$[220,221]$} \\
\hline
\end{tabular}


Table 2. Cont.

\begin{tabular}{|c|c|c|c|c|}
\hline Activator & Target & Outcome & Research Model & Reference \\
\hline \multicolumn{5}{|c|}{ Non-Polyphenol Compounds } \\
\hline Taurine * & Akt-CREB-PGC $1 \alpha$ & $\begin{array}{l}\downarrow \text { Glutamate cytotoxicity, maintain MMP, } \\
\downarrow \text { cytosolic ROS } \\
\downarrow \text { Mitochondrial ROS } \\
\uparrow \text { MMP, COX, ATP, SOD2 } \\
\uparrow \text { Hippocampal PGC } 1 \alpha \text { expression, learning and memory }\end{array}$ & $\begin{array}{l}\text { SH-SY5Y cells } \\
\text { prenatally-stressed rats that showed } \\
\text { defects in learning and memory }\end{array}$ & {$[222,223]$} \\
\hline$R$ - $\alpha$-Lipoic acid * & Akt/PI3K and Nrf2-ARE & $\begin{array}{l}\uparrow \text { HO- } 1 \text { expression, Nrf2 translocation } \\
\downarrow \text { ROS, } 4 \text { HNE, cell death }\end{array}$ & retinal neuronal RGC-5 cells & [228] \\
\hline Allicin * & Nrf2-ARE and neurotrophic & $\begin{array}{l}\downarrow \mathrm{A} \beta \text {-induced memory deficit } \\
\uparrow \text { Nrf2, antioxidant enzymes, } \\
\downarrow \text { PERK, p-tau, ROS, lipid peroxidation, protein carbonylation, } \\
\text { cognitive defect }\end{array}$ & $\begin{array}{l}\mathrm{AD} \text { mouse model } \\
\text { rat brains }\end{array}$ & {$[229,230]$} \\
\hline
\end{tabular}

( $\uparrow:$ increase; $\downarrow$ : decrease; * Natural compounds that can activate both Nrf2-ARE and neurotrophic signaling pathways.) 


\section{Discussion}

If briefly summarizing $A D$ pathogenesis, at early stage, $A \beta$ peptides and oxidative stress gradually overwhelms endogenous antioxidant system, thus increasing free reactive radicals. A $\beta$ peptides and free radicals attack mitochondria in concert with one another, thus perturbing mitochondrial ETC, depleting ATP, depolarizing MMP, generating MPTPs, and releasing ROS, RNS, and lipid peroxides. All the free reactive radicals directly damage DNA, proteins and intracellular organelles, causing synaptic defects and neuron death. Following oxidative damage and mitochondrial dysfunction, ER stress response system and autophagic process that govern proteo-homeostasis are losing their normal stance. Prolonged ER stress activates apoptotic pathways by hyper-activating ER stress controllers. Inhibition of autophagy by overactivated mTOR causes the accumulation of $\mathrm{A} \beta$ peptides and $\mathrm{p}$-tau, resulting in synaptic loss, neuron death, and cognitive decline in AD brains. All these multimodal processes make AD untreatable to current therapeutic approaches.

There has been an enormous amount of effort to find a better treatment strategy to attenuate oxidative stress and protect mitochondria. However, those efforts could not produce the positive outcome of modifying AD yet. Nonetheless, growing evidence indicates that the upregulation of global antioxidant defense system may be better for controlling oxidative stress-related pathogenesis in AD brains. Given that Nrf2 is the main switch of the expression of the majority of antioxidant enzymes and PGC1 $\alpha$ (mitochondria enhancer), activating Nrf2 appears to be a good therapeutic strategy to control oxidative stress in AD brains. FGFs, flavonoids, $R$ - $\alpha$-lipoic acid, allicin, and taurine appear to be able to activate the Nrf2-ARE antioxidant defense system.

In spite of the strength of the Nrf2-ARE antioxidant system, the system alone may not be sufficient to modify AD progress. Neurotrophic signaling pathway should be also activated to regenerate damaged organelles and molecules. As such, co-activation of the Nrf2-ARE system and neurotrophic signaling pathway is expected to generate a great synergism in changing AD progress. A group of natural products, indeed, can co-activate the Nrf2-ARE antioxidant system and neurotrophic signaling pathway; those include luteolin, apigenin, 7,8-DHF, harpagoside, taurine, and $R$ - $\alpha$-lipoic acid. It is unclear yet whether the products activate the neurotrophic signaling pathway and the Nrf2-ARE antioxidant system separately or not. Several lines of evidence suggest that neurotrophic signaling pathway may come upstream of the Nrf2-ARE system and control the expression of antioxidant enzymes. Clarifying how neurotrophic signaling pathway talks to the Nrf2-ARE antioxidant system would help to understand the mechanism by which the natural products activate both antioxidant and neurotrophic systems.

In addition to the identification of a multimodal-effect agent, there is another must-be-addressed question regarding the mechanism of action. How can the natural products activate the Nrf2-ARE defense system and/or neurotrophic signaling pathway? Except of 7,8-DHF, none of the neuroprotective natural products have shown their interacting cellular molecules that activate the Nrf2-ARE signaling pathway and/or neurotrophic signaling pathway. Given that the majority of signaling pathways start from plasma membrane receptors, it is very likely that the natural products have their own plasma membrane receptors. It is also possible that lipid-soluble natural products penetrate the plasma membrane and interact with intracellular signaling molecules. Identification of their cellular receptors should be given a priority in order to identify their neuroprotective mechanisms and speculate their possible off-target effects.

Although chronic ER stress and autophagy dysfunction are deeply involved in AD pathogenesis, it is still unclear whether those are AD triggers or the byproducts of AD pathogenesis. Apparently, chronic oxidative stress causes the accumulation of unfolded proteins that over-capacitate ER chaperoning system, thus triggering chronic ER stress. mTOR appears to be hyper-activated by loss of its upstream regulator such as pAkt as a result of decreased neurotrophic signaling in AD brains. Normal ER stress response system may be regain-able by neurotrophic signaling pathway in a similar way to $O$-demethylcurcumin [216]. Similarly, normal autophagic activity may be resume-able by suppressing mTOR via Akt. Therefore, activation of neurotrophic signaling pathway is expected to 
give additional benefits like attenuating chronic ER stress and autophagy dysfunction in addition to its neuro-regenerative effect.

In this review, we try to put puzzle pieces together to help find a better strategy to slow AD. Rather than using single-modal antioxidant treatment that shows little success in slowing AD [231], co-activation of the Nrf2-ARE antioxidant system and neurotrophic signaling pathway would provide a better chance to modify the multifaceted disease, AD. Fortunately, there are some natural products that activate the Nrf2-ARE antioxidant system and/or neurotrophic signaling pathway. Although their individual efficacies in enhancing antioxidant system and neurotrophic signaling pathway vary, a combinatory treatment using both Nrf2-activating product and neurotrophic product is worthy for clinical trials. It is also worthy of finding a way to increase the potency of single natural product that can activate both antioxidant and neurotrophic systems. Based on our review, we drew a model of synergism in slowing AD pathogenesis by either the combinatory use of neurotrophic product and Nrf2-activating product or the use of a multimodal-effect agent (Figure 3). In spite of the promise, lots of works are still required for more comprehensive analysis of the neurotrophic and/or antioxidant effects of each compound prior to their clinical trials. To this end, we believe that co-activation of the Nrf2-ARE antioxidant system and neurotrophic signaling pathway may be the best chance to modify AD.

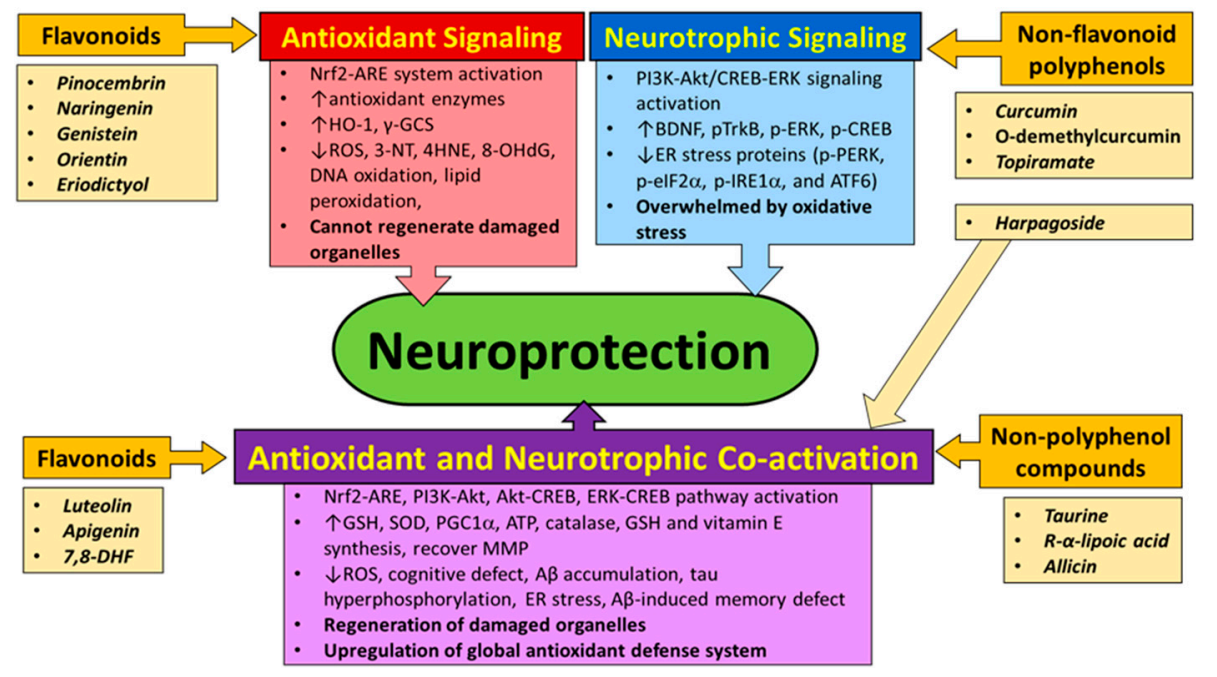

Figure 3. A better way to slow AD: Co-activation of the Nrf2-ARE antioxidant system and neurotrophic signaling pathway. In $\mathrm{AD}, \mathrm{A} \beta$ peptides and oxidative stress increase ROS, attack mitochondrial integrity and overpower antioxidant system. This leads to generation of lipid peroxides, DNA, protein and organelle damage, synaptic defects, increased ER stress response, and ultimately neuron death. In order to mitigate oxidative stress in $\mathrm{AD}$ brains, global antioxidant defense system should be upregulated. The activation of the Nrf2-ARE antioxidant defense system has been seen via FGFs and certain flavonoids. However, unilateral activation of the antioxidant system is insufficient in altering AD progression. Activation of neurotrophic signaling pathway is also necessary for regeneration of damaged organelles, which has been evidenced in various non-flavonoid polyphenols. Synergistic co-activation of the Nrf2-ARE system and neurotrophic signaling pathway, however, may provide a greater ameliorating effect on AD pathogenesis. Co-activation of these pathways can be achieved by either a combination of the Nrf2-ARE activator and neurotrophic signaling activator or a multimodal activator such as luteolin, apigenin, 7,8-DHF, harpagoside, taurine, and $R$ - $\alpha$-lipoic acid. Either combinatory treatment or strong multimodal-effect agent will have a greater ability of ameliorating or modifying the progression of multifaceted AD by co-activating antioxidant and neurotophic signaling pathways. ( $\uparrow$ : increase; $\downarrow$ : decrease). 
Acknowledgments: Our research work and publications have been supported by NIH grant 5 R21 AG053590-02 and deArce-Koch Memorial Endowment Fund.

Author Contributions: Kelsey E. Murphy contributes to manuscript writing, table generation, and figure drawing. Joshua J. Park contributes to manuscript designing and writing.

Conflicts of Interest: The authors declare no conflict of interest.

\section{Abbreviations}

\begin{tabular}{|c|c|}
\hline ABAD & A $\beta$-binding alcohol dehydrogenase \\
\hline $\mathrm{AD}$ & Alzheimer's disease \\
\hline AMPA & $\alpha$-Amino-3-hydroxy-5-methyl-4-isoxazole-propionic acid \\
\hline AMPK & AMP-activated protein kinase \\
\hline APP & Amyloid precursor protein \\
\hline ARE & Antioxidant response element \\
\hline ASK1 & Apoptosis signal-regulating kinase 1 \\
\hline ATF6 & Activating transcription factor 6 \\
\hline ATG & Autophagy-related protein \\
\hline ATP & Adenosine triphosphate \\
\hline BACE1 & $\beta$-Secretase 1 \\
\hline BBB & Blood brain barrier \\
\hline Bcl-2 & B-cell lymphoma 2 \\
\hline BDNF & Brain-derived neurotrophic factor \\
\hline BIM & Bcl-2 interacting mediator of cell death \\
\hline BVRs & Biliverdin reductases \\
\hline CaMKII & Calmodulin-dependent kinase II \\
\hline CHOP10 & $\mathrm{C} / \mathrm{EBP}$ homologous protein-10 \\
\hline COX & Cytochrome c oxidase \\
\hline CREB & cAMP response element binding protein \\
\hline CypD & Cyclophilin D \\
\hline cyt c & Cytochrome c \\
\hline 7,8-DHF & 7,8-dihydroxyflavone \\
\hline $\mathrm{eIF} 2 \alpha$ & eukaryotic translation initiation factor $2 \alpha$ \\
\hline ER & endoplasmic reticulum \\
\hline ERK & extracellular signal-regulated kinase \\
\hline $\mathrm{ERO} 1 \alpha$ & ER oxidase $1 \alpha$ \\
\hline $\mathrm{F}_{2}$-IsoPs & F2-isoprostanes \\
\hline FAK & focal adhesion kinase \\
\hline FGF & fibroblast growth factor \\
\hline FGL & flbroblast growth loop \\
\hline FIP200 & FAK-family interacting protein 200 \\
\hline GADD34 & Growth arrest and DNA damage-inducible protein 34 \\
\hline GAP-43 & Growth-associated protein 43 \\
\hline GCI & Global cerebral ischemia \\
\hline GCLM & Glutathione cysteine ligase modulatory subunit \\
\hline GCLC & Glutathione cysteine ligase regulatory subunit \\
\hline$\gamma$-GCS & $\gamma$-Glutamyl cysteine sythetase \\
\hline GPx & Glutathione peroxidase \\
\hline GR & Glutathione reductase \\
\hline GRP78 & Glucose-regulated protein 78 \\
\hline Grx & Glutaredoxin \\
\hline GS & Glutathione synthetase \\
\hline GSH & Glutathione \\
\hline GST & Glutathione $S$-transferase \\
\hline $4 \mathrm{HNE}$ & 4-Hydroxy-2-nonenal \\
\hline $\mathrm{HO}-1$ & Heme oxygenase 1 \\
\hline
\end{tabular}




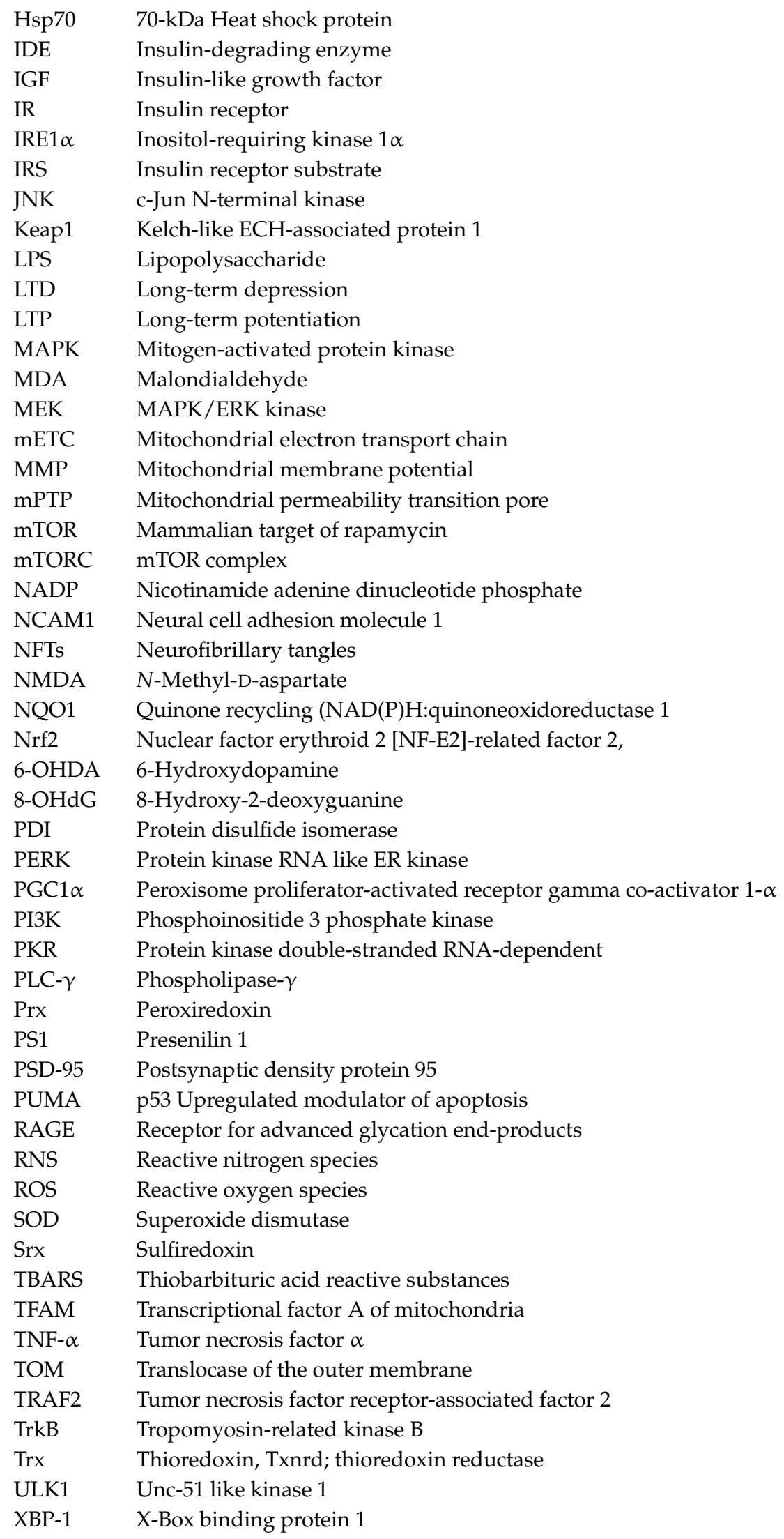




\section{References}

1. Barthet, G.; Georgakopoulos, A.; Robakis, N.K. Cellular mechanisms of $\gamma$-secretase substrate selection, processing and toxicity. Prog. Neurobiol. 2012, 98, 166-175. [CrossRef] [PubMed]

2. De Felice, F.G.; Velasco, P.T.; Lambert, M.P.; Viola, K.; Fernandez, S.J.; Ferreira, S.T.; Klein, W.L. A $\beta$ oligomers induce neuronal oxidative stress through an $N$-methyl-D-aspartate receptor-dependent mechanism that is blocked by the Alzheimer drug memantine. J. Biol. Chem. 2007, 282, 11590-11601. [CrossRef] [PubMed]

3. Nicholls, D.G. Mitochondrial function and dysfunction in the cell: Its relevance to aging and aging-related disease. Int. J. Biochem. Cell Biol. 2002, 34, 1372-1381. [CrossRef]

4. Ma, Q.L.; Yang, F.; Rosario, E.R.; Ubeda, O.J.; Beech, W.; Gant, D.J.; Chen, P.P.; Hudspeth, B.; Chen, C.; Zhao, Y.; et al. $\beta$-amyloid oligomers induce phosphorylation of tau and inactivation of insulin receptor substrate via c-Jun N-terminal kinase signaling: Suppression by omega-3 fatty acids and curcumin. J. Neurosci. 2009, 29, 9078-9089. [CrossRef] [PubMed]

5. Hong, S.; Beja-Glasser, V.F.; Nfonoyim, B.M.; Frouin, A.; Li, S.; Ramakrishnan, S.; Merry, K.M.; Shi, Q.; Rosenthal, A.; Barres, B.A.; et al. Complement and microglia mediate early synapse loss in Alzheimer mouse models. Science 2016, 352, 712-716. [CrossRef] [PubMed]

6. Kayed, R.; Lasagna-Reeves, C.A. Molecular mechanisms of amyloid oligomers toxicity. J. Alzheimer's Dis. 2013, 33 (Suppl. S1), S67-S78. [CrossRef] [PubMed]

7. Hsieh, H.; Boehm, J.; Sato, C.; Iwatsubo, T.; Tomita, T.; Sisodia, S.; Malinow, R. AMPAR removal underlies A $\beta$-induced synaptic depression and dendritic spine loss. Neuron 2006, 52, 831-843. [CrossRef] [PubMed]

8. Roselli, F.; Tirard, M.; Lu, J.; Hutzler, P.; Lamberti, P.; Livrea, P.; Morabito, M.; Almeida, O.F. Soluble $\beta$-amyloid1-40 induces NMDA-dependent degradation of postsynaptic density-95 at glutamatergic synapses. J. Neurosci. 2005, 25, 11061-11070. [CrossRef] [PubMed]

9. Selkoe, D.J. Alzheimer's disease is a synaptic failure. Science 2002, 298, 789-791. [CrossRef] [PubMed]

10. Li, S.; Hong, S.; Shepardson, N.E.; Walsh, D.M.; Shankar, G.M.; Selkoe, D. Soluble oligomers of amyloid $\beta$ protein facilitate hippocampal long-term depression by disrupting neuronal glutamate uptake. Neuron 2009, 62, 788-801. [CrossRef] [PubMed]

11. Shankar, G.M.; Li, S.; Mehta, T.H.; Garcia-Munoz, A.; Shepardson, N.E.; Smith, I.; Brett, F.M.; Farrell, M.A.; Rowan, M.J.; Lemere, C.A.; et al. Amyloid- $\beta$ protein dimers isolated directly from Alzheimer's brains impair synaptic plasticity and memory. Nat. Med. 2008, 14, 837-842. [CrossRef] [PubMed]

12. Moreira, P.I.; Cardoso, S.M.; Santos, M.S.; Oliveira, C.R. The key role of mitochondria in Alzheimer's disease. J. Alzheimer's Dis. 2006, 9, 101-110. [CrossRef]

13. Hauptmann, S.; Scherping, I.; Drose, S.; Brandt, U.; Schulz, K.L.; Jendrach, M.; Leuner, K.; Eckert, A.; Muller, W.E. Mitochondrial dysfunction: An early event in Alzheimer pathology accumulates with age in AD transgenic mice. Neurobiol. Aging 2009, 30, 1574-1586. [CrossRef] [PubMed]

14. Galindo, M.F.; Ikuta, I.; Zhu, X.; Casadesus, G.; Jordan, J. Mitochondrial biology in Alzheimer's disease pathogenesis. J. Neurochem. 2010, 114, 933-945. [CrossRef] [PubMed]

15. Mancuso, M.; Coppede, F.; Murri, L.; Siciliano, G. Mitochondrial cascade hypothesis of Alzheimer's disease: Myth or reality? Antioxid. Redox Signal. 2007, 9, 1631-1646. [CrossRef] [PubMed]

16. David, D.C.; Hauptmann, S.; Scherping, I.; Schuessel, K.; Keil, U.; Rizzu, P.; Ravid, R.; Drose, S.; Brandt, U.; Muller, W.E.; et al. Proteomic and functional analyses reveal a mitochondrial dysfunction in P301L tau transgenic mice. J. Biol. Chem. 2005, 280, 23802-23814. [CrossRef] [PubMed]

17. Zhang, W.; Hao, J.; Liu, R.; Zhang, Z.; Lei, G.; Su, C.; Miao, J.; Li, Z. Soluble A $\beta$ levels correlate with cognitive deficits in the 12-month-old APPswe/PS1dE9 mouse model of Alzheimer's disease. Behav. Brain Res. 2011, 222, 342-350. [CrossRef] [PubMed]

18. Delic, V.; Brownlow, M.; Joly-Amado, A.; Zivkovic, S.; Noble, K.; Phan, T.A.; Ta, Y.; Zhang, Y.; Bell, S.D.; Kurien, C.; et al. Calorie restriction does not restore brain mitochondrial function in P301L tau mice, but it does decrease mitochondrial F0F1-ATPase activity. Mol. Cell. Neurosci. 2015, 67, 46-54. [CrossRef] [PubMed]

19. Hansson Petersen, C.A.; Alikhani, N.; Behbahani, H.; Wiehager, B.; Pavlov, P.F.; Alafuzoff, I.; Leinonen, V.; Ito, A.; Winblad, B.; Glaser, E.; et al. The amyloid $\beta$-peptide is imported into mitochondria via the TOM import machinery and localized to mitochondrial cristae. Proc. Natl. Acad. Sci. USA 2008, 105, 13145-13150. [CrossRef] [PubMed] 
20. Takuma, K.; Fang, F.; Zhang, W.; Yan, S.; Fukuzaki, E.; Du, H.; Sosunov, A.; McKhann, G.; Funatsu, Y.; Nakamichi, N.; et al. RAGE-mediated signaling contributes to intraneuronal transport of amyloid- $\beta$ and neuronal dysfunction. Proc. Natl. Acad. Sci. USA 2009, 106, 20021-20026. [CrossRef] [PubMed]

21. Walther, K.A.; Grater, F.; Dougan, L.; Badilla, C.L.; Berne, B.J.; Fernandez, J.M. Signatures of hydrophobic collapse in extended proteins captured with force spectroscopy. Proc. Natl. Acad. Sci. USA 2007, 104, 7916-7921. [CrossRef] [PubMed]

22. Du, H.; Yan, S.S. Mitochondrial permeability transition pore in Alzheimer's disease: Cyclophilin D and amyloid $\beta$. Biochim. Biophys. Acta 2010, 1802, 198-204. [CrossRef] [PubMed]

23. Lustbader, J.W.; Cirilli, M.; Lin, C.; Xu, H.W.; Takuma, K.; Wang, N.; Caspersen, C.; Chen, X.; Pollak, S.; Chaney, M.; et al. ABAD directly links A $\beta$ to mitochondrial toxicity in Alzheimer's disease. Science 2004, 304, 448-452. [CrossRef] [PubMed]

24. Cha, M.Y.; Han, S.H.; Son, S.M.; Hong, H.S.; Choi, Y.J.; Byun, J.; Mook-Jung, I. Mitochondria-specific accumulation of amyloid $\beta$ induces mitochondrial dysfunction leading to apoptotic cell death. PLoS ONE 2012, 7, e34929. [CrossRef] [PubMed]

25. Casley, C.S.; Canevari, L.; Land, J.M.; Clark, J.B.; Sharpe, M.A. $\beta$-Amyloid inhibits integrated mitochondrial respiration and key enzyme activities. J. Neurochem. 2002, 80, 91-100. [CrossRef] [PubMed]

26. Manczak, M.; Anekonda, T.S.; Henson, E.; Park, B.S.; Quinn, J.; Reddy, P.H. Mitochondria are a direct site of A $\beta$ accumulation in Alzheimer's disease neurons: Implications for free radical generation and oxidative damage in disease progression. Hum. Mol. Genet. 2006, 15, 1437-1449. [CrossRef] [PubMed]

27. Caspersen, C.; Wang, N.; Yao, J.; Sosunov, A.; Chen, X.; Lustbader, J.W.; Xu, H.W.; Stern, D.; McKhann, G.; Yan, S.D. Mitochondrial A $\beta$ : A potential focal point for neuronal metabolic dysfunction in Alzheimer's disease. FASEB J. 2005, 19, 2040-2041. [PubMed]

28. Kim, T.S.; Pae, C.U.; Yoon, S.J.; Jang, W.Y.; Lee, N.J.; Kim, J.J.; Lee, S.J.; Lee, C.; Paik, I.H.; Lee, C.U. Decreased plasma antioxidants in patients with Alzheimer's disease. Int. J. Geriatr. Psychiatry 2006, 21, 344-348. [CrossRef] [PubMed]

29. Ghosh, D.; LeVault, K.R.; Barnett, A.J.; Brewer, G.J. A reversible early oxidized redox state that precedes macromolecular ROS damage in aging nontransgenic and 3xTg-AD mouse neurons. J. Neurosci. 2012, 32, 5821-5832. [CrossRef] [PubMed]

30. Aguilar, T.A.; Navarro, B.C.; Pérez, J.A. Endogenous Antioxidants: A Review of their Role in Oxidative Stress. In A Master Regulator of Oxidative Stress-The Transcription Factor Nrf2; InTech: Rijeka, Croatia, 2016; pp. 3-19.

31. Araújo, R.F.; Martins, D.B.; Borba, M.A. Oxidative Stress and Disease. In A Master Regulator of Oxidative Stress-The Transcription Factor Nrf2; InTech: Rijeka, Croatia, 2016; pp. 185-199.

32. Halliwell, B. Role of free radicals in the neurodegenerative diseases: Therapeutic implications for antioxidant treatment. Drugs Aging 2001, 18, 685-716. [CrossRef] [PubMed]

33. Patten, D.A.; Germain, M.; Kelly, M.A.; Slack, R.S. Reactive oxygen species: Stuck in the middle of neurodegeneration. J. Alzheimer's Dis. 2010, 20 (Suppl. S2), S357-S367. [CrossRef] [PubMed]

34. Toledo, J.C., Jr.; Augusto, O. Connecting the chemical and biological properties of nitric oxide. Chem. Res. Toxicol. 2012, 25, 975-989. [CrossRef] [PubMed]

35. Cui, H.; Chen, B.; Chicoine, L.G.; Nelin, L.D. Overexpression of cationic amino acid transporter-1 increases nitric oxide production in hypoxic human pulmonary microvascular endothelial cells. Clin. Exp. Pharmacol. Physiol. 2011, 38, 796-803. [CrossRef] [PubMed]

36. Adibhatla, R.M.; Hatcher, J.F. Lipid oxidation and peroxidation in CNS health and disease: From molecular mechanisms to therapeutic opportunities. Antioxid. Redox Signal. 2010, 12, 125-169. [CrossRef] [PubMed]

37. Hensley, K.; Maidt, M.L.; Yu, Z.; Sang, H.; Markesbery, W.R.; Floyd, R.A. Electrochemical analysis of protein nitrotyrosine and dityrosine in the Alzheimer brain indicates region-specific accumulation. J. Neurosci. 1998, 18, 8126-8132. [PubMed]

38. Smith, M.A.; Sayre, L.M.; Anderson, V.E.; Harris, P.L.; Beal, M.F.; Kowall, N.; Perry, G. Cytochemical demonstration of oxidative damage in Alzheimer disease by immunochemical enhancement of the carbonyl reaction with 2,4-dinitrophenylhydrazine. J. Histochem. Cytochem. 1998, 46, 731-735. [CrossRef] [PubMed]

39. Nunomura, A.; Perry, G.; Pappolla, M.A.; Wade, R.; Hirai, K.; Chiba, S.; Smith, M.A. RNA oxidation is a prominent feature of vulnerable neurons in Alzheimer's disease. J. Neurosci. 1999, 19, 1959-1964. [PubMed] 
40. Hensley, K.; Hall, N.; Subramaniam, R.; Cole, P.; Harris, M.; Aksenov, M.; Aksenova, M.; Gabbita, S.P.; $\mathrm{Wu}$, J.F.; Carney, J.M.; et al. Brain regional correspondence between Alzheimer's disease histopathology and biomarkers of protein oxidation. J. Neurochem. 1995, 65, 2146-2156. [CrossRef] [PubMed]

41. Lyras, L.; Cairns, N.J.; Jenner, A.; Jenner, P.; Halliwell, B. An assessment of oxidative damage to proteins, lipids, and DNA in brain from patients with Alzheimer's disease. J. Neurochem. 1997, 68, 2061-2069. [CrossRef] [PubMed]

42. Smith, M.A.; Richey Harris, P.L.; Sayre, L.M.; Beckman, J.S.; Perry, G. Widespread peroxynitrite-mediated damage in Alzheimer's disease. J. Neurosci. 1997, 17, 2653-2657. [PubMed]

43. Marcus, D.L.; Thomas, C.; Rodriguez, C.; Simberkoff, K.; Tsai, J.S.; Strafaci, J.A.; Freedman, M.L. Increased peroxidation and reduced antioxidant enzyme activity in Alzheimer's disease. Exp. Neurol. 1998, 150, 40-44. [CrossRef] [PubMed]

44. Ansari, M.A.; Scheff, S.W. Oxidative stress in the progression of Alzheimer disease in the frontal cortex. J. Neuropathol. Exp. Neurol. 2010, 69, 155-167. [CrossRef] [PubMed]

45. Lucassen, P.J.; Chung, W.C.; Kamphorst, W.; Swaab, D.F. DNA damage distribution in the human brain as shown by in situ end labeling; area-specific differences in aging and Alzheimer disease in the absence of apoptotic morphology. J. Neuropathol. Exp. Neurol. 1997, 56, 887-900. [CrossRef] [PubMed]

46. Butterfield, D.A.; Poon, H.F.; St Clair, D.; Keller, J.N.; Pierce, W.M.; Klein, J.B.; Markesbery, W.R. Redox proteomics identification of oxidatively modified hippocampal proteins in mild cognitive impairment: Insights into the development of Alzheimer's disease. Neurobiol. Dis. 2006, 22, 223-232. [CrossRef] [PubMed]

47. Williams, T.I.; Lynn, B.C.; Markesbery, W.R.; Lovell, M.A. Increased levels of 4-hydroxynonenal and acrolein, neurotoxic markers of lipid peroxidation, in the brain in Mild Cognitive Impairment and early Alzheimer's disease. Neurobiol. Aging 2006, 27, 1094-1109. [CrossRef] [PubMed]

48. Yao, Y.; Zhukareva, V.; Sung, S.; Clark, C.M.; Rokach, J.; Lee, V.M.; Trojanowski, J.Q.; Pratico, D. Enhanced brain levels of 8,12-iso-iPF2 $\alpha$-VI differentiate AD from frontotemporal dementia. Neurology 2003, 61, 475-478. [CrossRef] [PubMed]

49. Nakagawa, T.; Zhu, H.; Morishima, N.; Li, E.; Xu, J.; Yankner, B.A.; Yuan, J. Caspase-12 mediates endoplasmic-reticulum-specific apoptosis and cytotoxicity by amyloid- $\beta$. Nature 2000, 403, 98-103. [CrossRef] [PubMed]

50. Schroder, M.; Kaufman, R.J. ER stress and the unfolded protein response. Mutat. Res. 2005, 569, $29-63$. [CrossRef] [PubMed]

51. Harding, H.P.; Zhang, Y.; Ron, D. Protein translation and folding are coupled by an endoplasmic-reticulum-resident kinase. Nature 1999, 397, 271-274. [PubMed]

52. Novoa, I.; Zeng, H.; Harding, H.P.; Ron, D. Feedback inhibition of the unfolded protein response by GADD34-mediated dephosphorylation of eIF2 $\alpha$. J. Cell Biol. 2001, 153, 1011-1022. [CrossRef] [PubMed]

53. Ameri, K.; Harris, A.L. Activating transcription factor 4. Int. J. Biochem. Cell Biol. 2008, 40, 14-21. [CrossRef] [PubMed]

54. Hetz, C. The unfolded protein response: Controlling cell fate decisions under ER stress and beyond. Nat. Rev. Mol. Cell Biol. 2012, 13, 89-102. [CrossRef] [PubMed]

55. Yoshida, H.; Matsui, T.; Yamamoto, A.; Okada, T.; Mori, K. XBP1 mRNA is induced by ATF6 and spliced by IRE1 in response to ER stress to produce a highly active transcription factor. Cell 2001, 107, 881-891. [CrossRef]

56. Calfon, M.; Zeng, H.; Urano, F.; Till, J.H.; Hubbard, S.R.; Harding, H.P.; Clark, S.G.; Ron, D. IRE1 couples endoplasmic reticulum load to secretory capacity by processing the XBP-1 mRNA. Nature 2002, 415, 92-96. [CrossRef] [PubMed]

57. Hollien, J.; Lin, J.H.; Li, H.; Stevens, N.; Walter, P.; Weissman, J.S. Regulated Ire1-dependent decay of messenger RNAs in mammalian cells. J. Cell Biol. 2009, 186, 323-331. [CrossRef] [PubMed]

58. Ye, J.; Rawson, R.B.; Komuro, R.; Chen, X.; Dave, U.P.; Prywes, R.; Brown, M.S.; Goldstein, J.L. ER stress induces cleavage of membrane-bound ATF6 by the same proteases that process SREBPs. Mol. Cell 2000, 6, 1355-1364. [CrossRef]

59. Okada, T.; Yoshida, H.; Akazawa, R.; Negishi, M.; Mori, K. Distinct roles of activating transcription factor 6 (ATF6) and double-stranded RNA-activated protein kinase-like endoplasmic reticulum kinase (PERK) in transcription during the mammalian unfolded protein response. Biochem. J. 2002, 366 Pt 2, 585-594. [CrossRef] [PubMed] 
60. Yoshida, H.; Haze, K.; Yanagi, H.; Yura, T.; Mori, K. Identification of the cis-acting endoplasmic reticulum stress response element responsible for transcriptional induction of mammalian glucose-regulated proteins. Involvement of basic leucine zipper transcription factors. J. Biol. Chem. 1998, 273, 33741-33749. [CrossRef] [PubMed]

61. Han, J.; Back, S.H.; Hur, J.; Lin, Y.H.; Gildersleeve, R.; Shan, J.; Yuan, C.L.; Krokowski, D.; Wang, S.; Hatzoglou, M.; et al. ER-stress-induced transcriptional regulation increases protein synthesis leading to cell death. Nat. Cell Biol. 2013, 15, 481-490. [CrossRef] [PubMed]

62. Szegezdi, E.; Logue, S.E.; Gorman, A.M.; Samali, A. Mediators of endoplasmic reticulum stress-induced apoptosis. EMBO Rep. 2006, 7, 880-885. [CrossRef] [PubMed]

63. Shore, G.C.; Papa, F.R.; Oakes, S.A. Signaling cell death from the endoplasmic reticulum stress response. Curr. Opin. Cell Biol. 2011, 23, 143-149. [CrossRef] [PubMed]

64. Urra, H.; Dufey, E.; Lisbona, F.; Rojas-Rivera, D.; Hetz, C. When ER stress reaches a dead end. Biochim. Biophys. Acta 2013, 1833, 3507-3517. [CrossRef] [PubMed]

65. Er, E.; Oliver, L.; Cartron, P.F.; Juin, P.; Manon, S.; Vallette, F.M. Mitochondria as the target of the pro-apoptotic protein Bax. Biochim. Biophys. Acta 2006, 1757, 1301-1311. [CrossRef] [PubMed]

66. Oh, K.J.; Singh, P.; Lee, K.; Foss, K.; Lee, S.; Park, M.; Lee, S.; Aluvila, S.; Park, M.; Singh, P.; et al. Conformational changes in BAK, a pore-forming proapoptotic Bcl-2 family member, upon membrane insertion and direct evidence for the existence of $\mathrm{BH} 3-\mathrm{BH} 3$ contact interface in BAK homo-oligomers. J. Biol. Chem. 2010, 285, 28924-28937. [CrossRef] [PubMed]

67. Zhang, D.; Armstrong, J.S. Bax and the mitochondrial permeability transition cooperate in the release of cytochrome c during endoplasmic reticulum-stress-induced apoptosis. Cell Death Differ. 2007, 14, 703-715. [CrossRef] [PubMed]

68. Brush, M.H.; Weiser, D.C.; Shenolikar, S. Growth arrest and DNA damage-inducible protein GADD34 targets protein phosphatase $1 \alpha$ to the endoplasmic reticulum and promotes dephosphorylation of the $\alpha$ subunit of eukaryotic translation initiation factor 2. Mol. Cell. Biol. 2003, 23, 1292-1303. [CrossRef] [PubMed]

69. Kojima, E.; Takeuchi, A.; Haneda, M.; Yagi, A.; Hasegawa, T.; Yamaki, K.; Takeda, K.; Akira, S.; Shimokata, K.; Isobe, $\mathrm{K}$. The function of GADD34 is a recovery from a shutoff of protein synthesis induced by ER stress: Elucidation by GADD34-deficient mice. FASEB J. 2003, 17, 1573-1575. [CrossRef] [PubMed]

70. McCullough, K.D.; Martindale, J.L.; Klotz, L.O.; Aw, T.Y.; Holbrook, N.J. Gadd153 sensitizes cells to endoplasmic reticulum stress by down-regulating $\mathrm{Bcl} 2$ and perturbing the cellular redox state. Mol. Cell. Biol. 2001, 21, 1249-1259. [CrossRef] [PubMed]

71. Li, G.; Mongillo, M.; Chin, K.T.; Harding, H.; Ron, D.; Marks, A.R.; Tabas, I. Role of ERO1- $\alpha$-mediated stimulation of inositol 1,4,5-triphosphate receptor activity in endoplasmic reticulum stress-induced apoptosis. J. Cell Biol. 2009, 186, 783-792. [CrossRef] [PubMed]

72. Timmins, J.M.; Ozcan, L.; Seimon, T.A.; Li, G.; Malagelada, C.; Backs, J.; Backs, T.; Bassel-Duby, R.; Olson, E.N.; Anderson, M.E.; Tabas, I. Calcium/calmodulin-dependent protein kinase II links ER stress with Fas and mitochondrial apoptosis pathways. J. Clin. Investig. 2009, 119, 2925-2941. [CrossRef] [PubMed]

73. Tabas, I.; Ron, D. Integrating the mechanisms of apoptosis induced by endoplasmic reticulum stress. Nat. Cell Biol. 2011, 13, 184-190. [CrossRef] [PubMed]

74. Urano, F.; Wang, X.; Bertolotti, A.; Zhang, Y.; Chung, P.; Harding, H.P.; Ron, D. Coupling of stress in the ER to activation of JNK protein kinases by transmembrane protein kinase IRE1. Science 2000, 287, 664-666. [CrossRef] [PubMed]

75. Yoneda, T.; Imaizumi, K.; Oono, K.; Yui, D.; Gomi, F.; Katayama, T.; Tohyama, M. Activation of caspase-12, an endoplastic reticulum (ER) resident caspase, through tumor necrosis factor receptor-associated factor 2-dependent mechanism in response to the ER stress. J. Biol. Chem. 2001, 276, 13935-13940. [CrossRef] [PubMed]

76. Nishitoh, H.; Matsuzawa, A.; Tobiume, K.; Saegusa, K.; Takeda, K.; Inoue, K.; Hori, S.; Kakizuka, A.; Ichijo, H. ASK1 is essential for endoplasmic reticulum stress-induced neuronal cell death triggered by expanded polyglutamine repeats. Genes Dev. 2002, 16, 1345-1355. [CrossRef] [PubMed]

77. Hoozemans, J.J.; van Haastert, E.S.; Nijholt, D.A.; Rozemuller, A.J.; Eikelenboom, P.; Scheper, W. The unfolded protein response is activated in pretangle neurons in Alzheimer's disease hippocampus. Am. J. Pathol. 2009, 174, 1241-1251. [CrossRef] [PubMed] 
78. Roussel, B.D.; Kruppa, A.J.; Miranda, E.; Crowther, D.C.; Lomas, D.A.; Marciniak, S.J. Endoplasmic reticulum dysfunction in neurological disease. Lancet Neurol. 2013, 12, 105-118. [CrossRef]

79. Hoozemans, J.J.; Veerhuis, R.; Van Haastert, E.S.; Rozemuller, J.M.; Baas, F.; Eikelenboom, P.; Scheper, W. The unfolded protein response is activated in Alzheimer's disease. Acta Neuropathol. 2005, 110, 165-172. [CrossRef] [PubMed]

80. Honjo, Y.; Ito, H.; Horibe, T.; Takahashi, R.; Kawakami, K. Protein disulfide isomerase-immunopositive inclusions in patients with Alzheimer disease. Brain Res. 2010, 1349, 90-96. [CrossRef] [PubMed]

81. Costa-Mattioli, M.; Gobert, D.; Stern, E.; Gamache, K.; Colina, R.; Cuello, C.; Sossin, W.; Kaufman, R.; Pelletier, J.; Rosenblum, K.; et al. eIF2 $\alpha$ Phosphorylation bidirectionally regulates the switch from short- to long-term synaptic plasticity and memory. Cell 2007, 129, 195-206. [CrossRef] [PubMed]

82. Stern, E.; Chinnakkaruppan, A.; David, O.; Sonenberg, N.; Rosenblum, K. Blocking the eIF2 $\alpha$ kinase (PKR) enhances positive and negative forms of cortex-dependent taste memory. J. Neurosci. 2013, 33, 2517-2525. [CrossRef] [PubMed]

83. Di Prisco, G.V.; Huang, W.; Buffington, S.A.; Hsu, C.C.; Bonnen, P.E.; Placzek, A.N.; Sidrauski, C.; Krnjevic, K.; Kaufman, R.J.; Walter, P.; et al. Translational control of mGluR-dependent long-term depression and object-place learning by eIF2 $\alpha$. Nat. Neurosci. 2014, 17, 1073-1082. [CrossRef] [PubMed]

84. Jiang, Z.; Belforte, J.E.; Lu, Y.; Yabe, Y.; Pickel, J.; Smith, C.B.; Je, H.S.; Lu, B.; Nakazawa, K. eIF2 $\alpha$ Phosphorylation-dependent translation in CA1 pyramidal cells impairs hippocampal memory consolidation without affecting general translation. J. Neurosci. 2010, 30, 2582-2594. [CrossRef] [PubMed]

85. O'Connor, T.; Sadleir, K.R.; Maus, E.; Velliquette, R.A.; Zhao, J.; Cole, S.L.; Eimer, W.A.; Hitt, B.; Bembinster, L.A.; Lammich, S.; et al. Phosphorylation of the translation initiation factor eIF $2 \alpha$ increases BACE1 levels and promotes amyloidogenesis. Neuron 2008, 60, 988-1009. [CrossRef] [PubMed]

86. Sakagami, Y.; Kudo, T.; Tanimukai, H.; Kanayama, D.; Omi, T.; Horiguchi, K.; Okochi, M.; Imaizumi, K.; Takeda, M. Involvement of endoplasmic reticulum stress in tauopathy. Biochem. Biophys. Res. Commun. 2013, 430, 500-504. [CrossRef] [PubMed]

87. Ogata, M.; Hino, S.; Saito, A.; Morikawa, K.; Kondo, S.; Kanemoto, S.; Murakami, T.; Taniguchi, M.; Tanii, I.; Yoshinaga, K.; et al. Autophagy is activated for cell survival after endoplasmic reticulum stress. Mol. Cell Biol. 2006, 26, 9220-9231. [CrossRef] [PubMed]

88. Ulamek-Koziol, M.; Furmaga-Jablonska, W.; Januszewski, S.; Brzozowska, J.; Scislewska, M.; Jablonski, M.; Pluta, R. Neuronal autophagy: Self-eating or self-cannibalism in Alzheimer's disease. Neurochem. Res. 2013, 38, 1769-1773. [CrossRef] [PubMed]

89. Shimobayashi, M.; Hall, M.N. Making new contacts: The mTOR network in metabolism and signalling crosstalk. Nat. Rev. Mol. Cell Biol. 2014, 15, 155-162. [CrossRef] [PubMed]

90. Mizushima, N. The role of the Atg1/ULK1 complex in autophagy regulation. Curr. Opin. Cell Biol. 2010, 22, 132-139. [CrossRef] [PubMed]

91. Maiese, K.; Chong, Z.Z.; Wang, S.; Shang, Y.C. Oxidant stress and signal transduction in the nervous system with the PI 3-K, Akt, and mTOR cascade. Int. J. Mol. Sci. 2012, 13, 13830-13866. [CrossRef] [PubMed]

92. Kim, J.; Kundu, M.; Viollet, B.; Guan, K.L. AMPK and mTOR regulate autophagy through direct phosphorylation of Ulk1. Nat. Cell Biol. 2011, 13, 132-141. [CrossRef] [PubMed]

93. Hayashi-Nishino, M.; Fujita, N.; Noda, T.; Yamaguchi, A.; Yoshimori, T.; Yamamoto, A. A subdomain of the endoplasmic reticulum forms a cradle for autophagosome formation. Nat. Cell Biol. 2009, 11, 1433-1437. [CrossRef] [PubMed]

94. Mizushima, N.; Noda, T.; Ohsumi, Y. Apg16p is required for the function of the Apg12p-Apg5p conjugate in the yeast autophagy pathway. EMBO J. 1999, 18, 3888-3896. [CrossRef] [PubMed]

95. Yu, Z.Q.; Ni, T.; Hong, B.; Wang, H.Y.; Jiang, F.J.; Zou, S.; Chen, Y.; Zheng, X.L.; Klionsky, D.J.; Liang, Y.; et al. Dual roles of Atg8-PE deconjugation by Atg4 in autophagy. Autophagy 2012, 8, 883-892. [CrossRef] [PubMed]

96. Weidberg, H.; Shvets, E.; Shpilka, T.; Shimron, F.; Shinder, V.; Elazar, Z. LC3 and GATE-16/GABARAP subfamilies are both essential yet act differently in autophagosome biogenesis. EMBO J. 2010, 29, 1792-1802. [CrossRef] [PubMed]

97. Ichimura, Y.; Kumanomidou, T.; Sou, Y.S.; Mizushima, T.; Ezaki, J.; Ueno, T.; Kominami, E.; Yamane, T.; Tanaka, K.; Komatsu, M. Structural basis for sorting mechanism of p62 in selective autophagy. J. Biol. Chem. 2008, 283, 22847-22857. [CrossRef] [PubMed] 
98. C, O.N. PI3-kinase/Akt/mTOR signaling: Impaired on/off switches in aging, cognitive decline and Alzheimer's disease. Exp. Gerontol. 2013, 48, 647-653.

99. Caccamo, A.; Majumder, S.; Richardson, A.; Strong, R.; Oddo, S. Molecular interplay between mammalian target of rapamycin (mTOR), amyloid- $\beta$, and Tau: Effects on cognitive impairments. J. Biol. Chem. 2010, 285, 13107-13120. [CrossRef] [PubMed]

100. Spilman, P.; Podlutskaya, N.; Hart, M.J.; Debnath, J.; Gorostiza, O.; Bredesen, D.; Richardson, A.; Strong, R.; Galvan, V. Inhibition of mTOR by rapamycin abolishes cognitive deficits and reduces amyloid- $\beta$ levels in a mouse model of Alzheimer's disease. PLoS ONE 2010, 5, e9979. [CrossRef] [PubMed]

101. Zhu, Z.; Yan, J.; Jiang, W.; Yao, X.G.; Chen, J.; Chen, L.; Li, C.; Hu, L.; Jiang, H.; Shen, X. Arctigenin effectively ameliorates memory impairment in Alzheimer's disease model mice targeting both $\beta$-amyloid production and clearance. J. Neurosci. 2013, 33, 13138-13149. [CrossRef] [PubMed]

102. Hamano, T.; Gendron, T.F.; Causevic, E.; Yen, S.H.; Lin, W.L.; Isidoro, C.; Deture, M.; Ko, L.W. Autophagic-lysosomal perturbation enhances tau aggregation in transfectants with induced wild-type tau expression. Eur. J. Neurosci. 2008, 27, 1119-1130. [CrossRef] [PubMed]

103. Caccamo, A.; De Pinto, V.; Messina, A.; Branca, C.; Oddo, S. Genetic reduction of mammalian target of rapamycin ameliorates Alzheimer's disease-like cognitive and pathological deficits by restoring hippocampal gene expression signature. J. Neurosci. 2014, 34, 7988-7998. [CrossRef] [PubMed]

104. Zhang, M.; An, C.; Gao, Y.; Leak, R.K.; Chen, J.; Zhang, F. Emerging roles of Nrf2 and phase II antioxidant enzymes in neuroprotection. Prog. Neurobiol. 2013, 100, 30-47. [CrossRef] [PubMed]

105. Lo Gerfo, A.; Petrozzi, L.; Chico, L.; Siciliano, G. Nrf2 Signaling: An Adaptive Response Pathway for Neurodegenerative Disorders. In A Master Regulator of Oxidative Stress-The Transcription Factor Nrf2; InTech: Rijeka, Croatia, 2016; pp. 145-166.

106. Johnson, D.A.; Johnson, J.A. Nrf2-A therapeutic target for the treatment of neurodegenerative diseases. Free Radic. Biol. Med. 2015, 88 Pt B, 253-267. [CrossRef] [PubMed]

107. Kobayashi, A.; Kang, M.I.; Okawa, H.; Ohtsuji, M.; Zenke, Y.; Chiba, T.; Igarashi, K.; Yamamoto, M. Oxidative stress sensor Keap1 functions as an adaptor for Cul3-based E3 ligase to regulate proteasomal degradation of Nrf2. Mol. Cell. Biol. 2004, 24, 7130-7139. [CrossRef] [PubMed]

108. Scapagnini, G.; Vasto, S.; Abraham, N.G.; Caruso, C.; Zella, D.; Fabio, G. Modulation of Nrf2/ARE pathway by food polyphenols: A nutritional neuroprotective strategy for cognitive and neurodegenerative disorders. Mol. Neurobiol. 2011, 44, 192-201. [CrossRef] [PubMed]

109. Calkins, M.J.; Johnson, D.A.; Townsend, J.A.; Vargas, M.R.; Dowell, J.A.; Williamson, T.P.; Kraft, A.D.; Lee, J.M.; Li, J.; Johnson, J.A. The Nrf2/ARE pathway as a potential therapeutic target in neurodegenerative disease. Antioxid. Redox Signal. 2009, 11, 497-508. [CrossRef] [PubMed]

110. De Vries, H.E.; Witte, M.; Hondius, D.; Rozemuller, A.J.; Drukarch, B.; Hoozemans, J.; van Horssen, J. Nrf2-induced antioxidant protection: A promising target to counteract ROS-mediated damage in neurodegenerative disease? Free Radic. Biol. Med. 2008, 45, 1375-1383. [CrossRef] [PubMed]

111. Yenki, P.; Khodagholi, F.; Shaerzadeh, F. Inhibition of phosphorylation of JNK suppresses A $\beta$-induced ER stress and upregulates prosurvival mitochondrial proteins in rat hippocampus. J. Mol. Neurosci. 2013, 49, 262-269. [CrossRef] [PubMed]

112. Miyamoto, N.; Izumi, H.; Miyamoto, R.; Kondo, H.; Tawara, A.; Sasaguri, Y.; Kohno, K. Quercetin induces the expression of peroxiredoxins 3 and 5 via the Nrf2/NRF1 transcription pathway. Investig. Ophthalmol. Vis. Sci. 2011, 52, 1055-1063. [CrossRef] [PubMed]

113. Maines, M.D.; Trakshel, G.M.; Kutty, R.K. Characterization of two constitutive forms of rat liver microsomal heme oxygenase. Only one molecular species of the enzyme is inducible. J. Biol. Chem. 1986, 261, 411-419. [PubMed]

114. Schipper, H.M. Heme oxygenase-1: Role in brain aging and neurodegeneration. Exp. Gerontol. 2000, 35, 821-830. [CrossRef]

115. Barone, E.; Di Domenico, F.; Sultana, R.; Coccia, R.; Mancuso, C.; Perluigi, M.; Butterfield, D.A. Heme oxygenase-1 posttranslational modifications in the brain of subjects with Alzheimer disease and mild cognitive impairment. Free Radic. Biol. Med. 2012, 52, 2292-2301. [CrossRef] [PubMed]

116. Zhang, L.; Yu, H.; Zhao, X.; Lin, X.; Tan, C.; Cao, G.; Wang, Z. Neuroprotective effects of salidroside against $\beta$-amyloid-induced oxidative stress in SH-SY5Y human neuroblastoma cells. Neurochem. Int. 2010, 57, 547-555. [CrossRef] [PubMed] 
117. Maines, M.D. The heme oxygenase system: A regulator of second messenger gases. Annu. Rev. Pharmacol. Toxicol. 1997, 37, 517-554. [CrossRef] [PubMed]

118. Kapitulnik, J.; Maines, M.D. Pleiotropic functions of biliverdin reductase: Cellular signaling and generation of cytoprotective and cytotoxic bilirubin. Trends Pharmacol. Sci. 2009, 30, 129-137. [CrossRef] [PubMed]

119. Dore, S.; Snyder, S.H. Neuroprotective action of bilirubin against oxidative stress in primary hippocampal cultures. Ann. N. Y. Acad. Sci. 1999, 890, 167-172. [CrossRef] [PubMed]

120. Takeda, A.; Itoyama, Y.; Kimpara, T.; Zhu, X.; Avila, J.; Dwyer, B.E.; Perry, G.; Smith, M.A. Heme catabolism and heme oxygenase in neurodegenerative disease. Antioxid. Redox Signal. 2004, 6, 888-894. [CrossRef] [PubMed]

121. Barone, E.; Di Domenico, F.; Mancuso, C.; Butterfield, D.A. The Janus face of the heme oxygenase/biliverdin reductase system in Alzheimer disease: It's time for reconciliation. Neurobiol. Dis. 2014, 62, 144-159. [CrossRef] [PubMed]

122. Okado-Matsumoto, A.; Fridovich, I. Subcellular distribution of superoxide dismutases (SOD) in rat liver: Cu,Zn-SOD in mitochondria. J. Biol. Chem. 2001, 276, 38388-38393. [CrossRef] [PubMed]

123. Ma, T.; Hoeffer, C.A.; Wong, H.; Massaad, C.A.; Zhou, P.; Iadecola, C.; Murphy, M.P.; Pautler, R.G.; Klann, E. Amyloid $\beta$-induced impairments in hippocampal synaptic plasticity are rescued by decreasing mitochondrial superoxide. J. Neurosci. 2011, 31, 5589-5595. [CrossRef] [PubMed]

124. Murphy, M.P. How mitochondria produce reactive oxygen species. Biochem. J. 2009, 417, 1-13. [CrossRef] [PubMed]

125. Esposito, L.; Raber, J.; Kekonius, L.; Yan, F.; Yu, G.Q.; Bien-Ly, N.; Puolivali, J.; Scearce-Levie, K.; Masliah, E.; Mucke, L. Reduction in mitochondrial superoxide dismutase modulates Alzheimer's disease-like pathology and accelerates the onset of behavioral changes in human amyloid precursor protein transgenic mice. J. Neurosci. 2006, 26, 5167-5179. [CrossRef] [PubMed]

126. Li, F.; Calingasan, N.Y.; Yu, F.; Mauck, W.M.; Toidze, M.; Almeida, C.G.; Takahashi, R.H.; Carlson, G.A.; Flint Beal, M.; Lin, M.T.; et al. Increased plaque burden in brains of APP mutant MnSOD heterozygous knockout mice. J. Neurochem. 2004, 89, 1308-1312. [CrossRef] [PubMed]

127. Dumont, M.; Wille, E.; Stack, C.; Calingasan, N.Y.; Beal, M.F.; Lin, M.T. Reduction of oxidative stress, amyloid deposition, and memory deficit by manganese superoxide dismutase overexpression in a transgenic mouse model of Alzheimer's disease. FASEB J. 2009, 23, 2459-2466. [CrossRef] [PubMed]

128. Massaad, C.A.; Washington, T.M.; Pautler, R.G.; Klann, E. Overexpression of SOD-2 reduces hippocampal superoxide and prevents memory deficits in a mouse model of Alzheimer's disease. Proc. Natl. Acad. Sci. USA 2009, 106, 13576-13581. [CrossRef] [PubMed]

129. Lin, M.T.; Beal, M.F. Mitochondrial dysfunction and oxidative stress in neurodegenerative diseases. Nature 2006, 443, 787-795. [CrossRef] [PubMed]

130. Ferrer-Sueta, G.; Radi, R. Chemical biology of peroxynitrite: Kinetics, diffusion, and radicals. ACS Chem. Biol. 2009, 4, 161-177. [CrossRef] [PubMed]

131. Holmgren, A.; Lu, J. Thioredoxin and thioredoxin reductase: Current research with special reference to human disease. Biochem. Biophys. Res. Commun. 2010, 396, 120-124. [CrossRef] [PubMed]

132. Lillig, C.H.; Berndt, C.; Holmgren, A. Glutaredoxin systems. Biochim. Biophys. Acta 2008, 1780, $1304-1317$. [CrossRef] [PubMed]

133. Strange, R.C.; Spiteri, M.A.; Ramachandran, S.; Fryer, A.A. Glutathione-S-transferase family of enzymes. Mutat. Res. 2001, 482, 21-26. [CrossRef]

134. Ramsey, C.P.; Glass, C.A.; Montgomery, M.B.; Lindl, K.A.; Ritson, G.P.; Chia, L.A.; Hamilton, R.L.; Chu, C.T.; Jordan-Sciutto, K.L. Expression of Nrf2 in neurodegenerative diseases. J. Neuropathol. Exp. Neurol. 2007, 66, 75-85. [CrossRef] [PubMed]

135. Joshi, G.; Johnson, J.A. The Nrf2-ARE pathway: A valuable therapeutic target for the treatment of neurodegenerative diseases. Recent Pat. CNS Drug Discov. 2012, 7, 218-229. [CrossRef] [PubMed]

136. Joshi, G.; Gan, K.A.; Johnson, D.A.; Johnson, J.A. Increased Alzheimer's disease-like pathology in the APP/PS1DeltaE9 mouse model lacking Nrf2 through modulation of autophagy. Neurobiol. Aging 2015, 36, 664-679. [CrossRef] [PubMed]

137. Kanninen, K.; Malm, T.M.; Jyrkkanen, H.K.; Goldsteins, G.; Keksa-Goldsteine, V.; Tanila, H.; Yamamoto, M.; Yla-Herttuala, S.; Levonen, A.L.; Koistinaho, J. Nuclear factor erythroid 2-related factor 2 protects against $\beta$ amyloid. Mol. Cell. Neurosci. 2008, 39, 302-313. [CrossRef] [PubMed] 
138. Ghosh, D.; LeVault, K.R.; Brewer, G.J. Dual-energy precursor and nuclear erythroid-related factor 2 activator treatment additively improve redox glutathione levels and neuron survival in aging and Alzheimer mouse neurons upstream of reactive oxygen species. Neurobiol. Aging 2014, 35, 179-190. [CrossRef] [PubMed]

139. Dumont, M.; Wille, E.; Calingasan, N.Y.; Tampellini, D.; Williams, C.; Gouras, G.K.; Liby, K.; Sporn, M.; Nathan, C.; Flint Beal, M.; et al. Triterpenoid CDDO-methylamide improves memory and decreases amyloid plaques in a transgenic mouse model of Alzheimer's disease. J. Neurochem. 2009, 109, 502-512. [CrossRef] [PubMed]

140. Gan, L.; Vargas, M.R.; Johnson, D.A.; Johnson, J.A. Astrocyte-specific overexpression of Nrf2 delays motor pathology and synuclein aggregation throughout the CNS in the $\alpha$-synuclein mutant (A53T) mouse model. J. Neurosci. 2012, 32, 17775-17787. [CrossRef] [PubMed]

141. Im, J.Y.; Lee, K.W.; Woo, J.M.; Junn, E.; Mouradian, M.M. DJ-1 induces thioredoxin 1 expression through the Nrf2 pathway. Hum. Mol. Genet. 2012, 21, 3013-3024. [CrossRef] [PubMed]

142. Ren, H.; Fu, K.; Wang, D.; Mu, C.; Wang, G. Oxidized DJ-1 interacts with the mitochondrial protein BCL-XL. J. Biol. Chem. 2011, 286, 35308-35317. [CrossRef] [PubMed]

143. Zhou, W.; Zhu, M.; Wilson, M.A.; Petsko, G.A.; Fink, A.L. The oxidation state of DJ-1 regulates its chaperone activity toward $\alpha$-synuclein. J. Mol. Biol. 2006, 356, 1036-1048. [CrossRef] [PubMed]

144. Benito, E.; Barco, A. CREB's control of intrinsic and synaptic plasticity: Implications for CREB-dependent memory models. Trends Neurosci. 2010, 33, 230-240. [CrossRef] [PubMed]

145. Barco, A.; Marie, H. Genetic approaches to investigate the role of CREB in neuronal plasticity and memory. Mol. Neurobiol. 2011, 44, 330-349. [CrossRef] [PubMed]

146. Lee, J.; Kim, C.H.; Simon, D.K.; Aminova, L.R.; Andreyev, A.Y.; Kushnareva, Y.E.; Murphy, A.N.; Lonze, B.E.; Kim, K.S.; Ginty, D.D.; et al. Mitochondrial cyclic AMP response element-binding protein (CREB) mediates mitochondrial gene expression and neuronal survival. J. Biol. Chem. 2005, 280, 40398-40401. [CrossRef] [PubMed]

147. Satoh, Y.; Kobayashi, Y.; Takeuchi, A.; Pages, G.; Pouyssegur, J.; Kazama, T. Deletion of ERK1 and ERK2 in the CNS causes cortical abnormalities and neonatal lethality: Erk1 deficiency enhances the impairment of neurogenesis in Erk2-deficient mice. J. Neurosci. 2011, 31, 1149-1155. [CrossRef] [PubMed]

148. Parmar, M.S.; Jaumotte, J.D.; Wyrostek, S.L.; Zigmond, M.J.; Cavanaugh, J.E. Role of ERK1, 2, and 5 in dopamine neuron survival during aging. Neurobiol. Aging 2014, 35, 669-679. [CrossRef] [PubMed]

149. Hetman, M.; Gozdz, A. Role of extracellular signal regulated kinases 1 and 2 in neuronal survival. Eur. J. Biochem. 2004, 271, 2050-2055. [CrossRef] [PubMed]

150. Cowansage, K.K.; LeDoux, J.E.; Monfils, M.H. Brain-derived neurotrophic factor: A dynamic gatekeeper of neural plasticity. Curr. Mol. Pharmacol. 2010, 3, 12-29. [CrossRef] [PubMed]

151. Minichiello, L. TrkB signalling pathways in LTP and learning. Nat. Rev. Neurosci. 2009, 10, 850-860. [CrossRef] [PubMed]

152. Jiang, X.; Tian, F.; Mearow, K.; Okagaki, P.; Lipsky, R.H.; Marini, A.M. The excitoprotective effect of $\mathrm{N}$-methyl-D-aspartate receptors is mediated by a brain-derived neurotrophic factor autocrine loop in cultured hippocampal neurons. J. Neurochem. 2005, 94, 713-722. [CrossRef] [PubMed]

153. Kaplan, D.R.; Miller, F.D. Neurotrophin signal transduction in the nervous system. Curr. Opin. Neurobiol. 2000, 10, 381-391. [CrossRef]

154. Patapoutian, A.; Reichardt, L.F. Trk receptors: Mediators of neurotrophin action. Curr. Opin. Neurobiol. 2001, 11, 272-280. [CrossRef]

155. Beck, T.; Lindholm, D.; Castren, E.; Wree, A. Brain-derived neurotrophic factor protects against ischemic cell damage in rat hippocampus. J. Cereb. Blood Flow Metab. 1994, 14, 689-692. [CrossRef] [PubMed]

156. Schabitz, W.R.; Sommer, C.; Zoder, W.; Kiessling, M.; Schwaninger, M.; Schwab, S. Intravenous brain-derived neurotrophic factor reduces infarct size and counterregulates Bax and Bcl-2 expression after temporary focal cerebral ischemia. Stroke 2000, 31, 2212-2217. [CrossRef] [PubMed]

157. Almeida, R.D.; Manadas, B.J.; Melo, C.V.; Gomes, J.R.; Mendes, C.S.; Graos, M.M.; Carvalho, R.F.; Carvalho, A.P.; Duarte, C.B. Neuroprotection by BDNF against glutamate-induced apoptotic cell death is mediated by ERK and PI3-kinase pathways. Cell Death Differ. 2005, 12, 1329-1343. [CrossRef] [PubMed]

158. Murer, M.G.; Yan, Q.; Raisman-Vozari, R. Brain-derived neurotrophic factor in the control human brain, and in Alzheimer's disease and Parkinson's disease. Prog. Neurobiol. 2001, 63, 71-124. [CrossRef] 
159. Michalski, B.; Fahnestock, M. Pro-brain-derived neurotrophic factor is decreased in parietal cortex in Alzheimer's disease. Brain Res. Mol. Brain Res. 2003, 111, 148-154. [CrossRef]

160. Peng, S.; Wuu, J.; Mufson, E.J.; Fahnestock, M. Precursor form of brain-derived neurotrophic factor and mature brain-derived neurotrophic factor are decreased in the pre-clinical stages of Alzheimer's disease. J. Neurochem. 2005, 93, 1412-1421. [CrossRef] [PubMed]

161. Christensen, R.; Marcussen, A.B.; Wortwein, G.; Knudsen, G.M.; Aznar, S. A $\beta(1-42)$ injection causes memory impairment, lowered cortical and serum BDNF levels, and decreased hippocampal 5-HT(2A) levels. Exp. Neurol. 2008, 210, 164-171. [CrossRef] [PubMed]

162. Peng, S.; Garzon, D.J.; Marchese, M.; Klein, W.; Ginsberg, S.D.; Francis, B.M.; Mount, H.T.; Mufson, E.J.; Salehi, A.; Fahnestock, M. Decreased brain-derived neurotrophic factor depends on amyloid aggregation state in transgenic mouse models of Alzheimer's disease. J. Neurosci. 2009, 29, 9321-9329. [CrossRef] [PubMed]

163. Zuccato, C.; Cattaneo, E. Brain-derived neurotrophic factor in neurodegenerative diseases. Nat. Rev. Neurol. 2009, 5, 311-322. [CrossRef] [PubMed]

164. Stockhorst, U.; de Fries, D.; Steingrueber, H.J.; Scherbaum, W.A. Insulin and the CNS: Effects on food intake, memory, and endocrine parameters and the role of intranasal insulin administration in humans. Physiol. Behav. 2004, 83, 47-54. [CrossRef]

165. Hoyer, S. Glucose metabolism and insulin receptor signal transduction in Alzheimer disease. Eur. J. Pharmacol. 2004, 490, 115-125. [CrossRef] [PubMed]

166. Benedict, C.; Hallschmid, M.; Hatke, A.; Schultes, B.; Fehm, H.L.; Born, J.; Kern, W. Intranasal insulin improves memory in humans. Psychoneuroendocrinology 2004, 29, 1326-1334. [CrossRef] [PubMed]

167. Zhao, W.; Chen, H.; Xu, H.; Moore, E.; Meiri, N.; Quon, M.J.; Alkon, D.L. Brain insulin receptors and spatial memory. Correlated changes in gene expression, tyrosine phosphorylation, and signaling molecules in the hippocampus of water maze trained rats. J. Biol. Chem. 1999, 274, 34893-34902. [CrossRef] [PubMed]

168. Freude, S.; Schilbach, K.; Schubert, M. The role of IGF-1 receptor and insulin receptor signaling for the pathogenesis of Alzheimer's disease: From model organisms to human disease. Curr. Alzheimer Res. 2009, 6, 213-323. [CrossRef] [PubMed]

169. De la Monte, S.M.; Wands, J.R. Review of insulin and insulin-like growth factor expression, signaling, and malfunction in the central nervous system: Relevance to Alzheimer's disease. J. Alzheimer's Dis. 2005, 7, 45-61. [CrossRef]

170. Plum, L.; Schubert, M.; Bruning, J.C. The role of insulin receptor signaling in the brain. Trends Endocrinol. Metab. 2005, 16, 59-65. [CrossRef] [PubMed]

171. Shankar, G.M.; Bloodgood, B.L.; Townsend, M.; Walsh, D.M.; Selkoe, D.J.; Sabatini, B.L. Natural oligomers of the Alzheimer amyloid- $\beta$ protein induce reversible synapse loss by modulating an NMDA-type glutamate receptor-dependent signaling pathway. J. Neurosci. 2007, 27, 2866-2875. [CrossRef] [PubMed]

172. Horwood, J.M.; Dufour, F.; Laroche, S.; Davis, S. Signalling mechanisms mediated by the phosphoinositide 3-kinase/Akt cascade in synaptic plasticity and memory in the rat. Eur. J. Neurosci. 2006, 23, 3375-3384. [CrossRef] [PubMed]

173. Condorelli, F.; Salomoni, P.; Cotteret, S.; Cesi, V.; Srinivasula, S.M.; Alnemri, E.S.; Calabretta, B. Caspase cleavage enhances the apoptosis-inducing effects of BAD. Mol. Cell Biol. 2001, 21, 3025-3036. [CrossRef] [PubMed]

174. Halestrap, A.P.; Doran, E.; Gillespie, J.P.; O’Toole, A. Mitochondria and cell death. Biochem. Soc. Trans. 2000, 28, 170-177. [CrossRef] [PubMed]

175. Zhao, L.; Teter, B.; Morihara, T.; Lim, G.P.; Ambegaokar, S.S.; Ubeda, O.J.; Frautschy, S.A.; Cole, G.M. Insulin-degrading enzyme as a downstream target of insulin receptor signaling cascade: Implications for Alzheimer's disease intervention. J. Neurosci. 2004, 24, 11120-11126. [CrossRef] [PubMed]

176. Farris, W.; Mansourian, S.; Chang, Y.; Lindsley, L.; Eckman, E.A.; Frosch, M.P.; Eckman, C.B.; Tanzi, R.E.; Selkoe, D.J.; Guenette, S. Insulin-degrading enzyme regulates the levels of insulin, amyloid $\beta$-protein, and the $\beta$-amyloid precursor protein intracellular domain in vivo. Proc. Natl. Acad. Sci. USA 2003, 100, 4162-4167. [CrossRef] [PubMed]

177. Watson, G.S.; Peskind, E.R.; Asthana, S.; Purganan, K.; Wait, C.; Chapman, D.; Schwartz, M.W.; Plymate, S.; Craft, S. Insulin increases CSF A $\beta 42$ levels in normal older adults. Neurology 2003, 60, 1899-1903. [CrossRef] [PubMed] 
178. Dudek, H.; Datta, S.R.; Franke, T.F.; Birnbaum, M.J.; Yao, R.; Cooper, G.M.; Segal, R.A.; Kaplan, D.R.; Greenberg, M.E. Regulation of neuronal survival by the serine-threonine protein kinase Akt. Science 1997, 275, 661-665. [CrossRef] [PubMed]

179. Banks, W.A.; Dohgu, S.; Lynch, J.L.; Fleegal-DeMotta, M.A.; Erickson, M.A.; Nakaoke, R.; Vo, T.Q. Nitric oxide isoenzymes regulate lipopolysaccharide-enhanced insulin transport across the blood-brain barrier. Endocrinology 2008, 149, 1514-1523. [CrossRef] [PubMed]

180. Reger, M.A.; Watson, G.S.; Frey, W.H., 2nd; Baker, L.D.; Cholerton, B.; Keeling, M.L.; Belongia, D.A.; Fishel, M.A.; Plymate, S.R.; Schellenberg, G.D.; et al. Effects of intranasal insulin on cognition in memory-impaired older adults: Modulation by APOE genotype. Neurobiol. Aging 2006, 27, 451-458. [CrossRef] [PubMed]

181. Dhamoon, M.S.; Noble, J.M.; Craft, S. Intranasal insulin improves cognition and modulates $\beta$-amyloid in early AD. Neurology 2009, 72, 292-293. [CrossRef] [PubMed]

182. Peltier, J.; O'Neill, A.; Schaffer, D.V. PI3K/Akt and CREB regulate adult neural hippocampal progenitor proliferation and differentiation. Dev. Neurobiol. 2007, 67, 1348-1361. [CrossRef] [PubMed]

183. Soto, I.; Rosenthal, J.J.; Blagburn, J.M.; Blanco, R.E. Fibroblast growth factor 2 applied to the optic nerve after axotomy up-regulates BDNF and TrkB in ganglion cells by activating the ERK and PKA signaling pathways. J. Neurochem. 2006, 96, 82-96. [CrossRef] [PubMed]

184. Barraud, P.; He, X.; Zhao, C.; Caldwell, M.A.; Franklin, R.J. FGF but not EGF induces phosphorylation of the cAMP response element binding protein in olfactory mucosa-derived cell cultures. Exp. Cell Res. 2010, 316, 1489-1499. [CrossRef] [PubMed]

185. Vargas, M.R.; Pehar, M.; Cassina, P.; Martinez-Palma, L.; Thompson, J.A.; Beckman, J.S.; Barbeito, L. Fibroblast growth factor-1 induces heme oxygenase-1 via nuclear factor erythroid 2-related factor 2 (Nrf2) in spinal cord astrocytes: Consequences for motor neuron survival. J. Biol. Chem. 2005, 280, 25571-25579. [CrossRef] [PubMed]

186. Huang, J.Y.; Chuang, J.I. Fibroblast growth factor 9 upregulates heme oxygenase- 1 and $\gamma$-glutamylcysteine synthetase expression to protect neurons from 1-methyl-4-phenylpyridinium toxicity. Free Radic. Biol. Med. 2010, 49, 1099-1108. [CrossRef] [PubMed]

187. Chuang, J.I.; Huang, J.Y.; Tsai, S.J.; Sun, H.S.; Yang, S.H.; Chuang, P.C.; Huang, B.M.; Ching, C.H. FGF9-induced changes in cellular redox status and HO-1 upregulation are FGFR-dependent and proceed through both ERK and AKT to induce CREB and Nrf2 activation. Free Radic. Biol. Med. 2015, 89, 274-286. [CrossRef] [PubMed]

188. Zeldich, E.; Chen, C.D.; Colvin, T.A.; Bove-Fenderson, E.A.; Liang, J.; Tucker Zhou, T.B.; Harris, D.A.; Abraham, C.R. The neuroprotective effect of Klotho is mediated via regulation of members of the redox system. J. Biol. Chem. 2014, 289, 24700-24715. [CrossRef] [PubMed]

189. Anderson, A.A.; Kendal, C.E.; Garcia-Maya, M.; Kenny, A.V.; Morris-Triggs, S.A.; Wu, T.; Reynolds, R.; Hohenester, E.; Saffell, J.L. A peptide from the first fibronectin domain of NCAM acts as an inverse agonist and stimulates FGF receptor activation, neurite outgrowth and survival. J. Neurochem. 2005, 95, 570-583. [CrossRef] [PubMed]

190. Moosavi, F.; Hosseini, R.; Saso, L.; Firuzi, O. Modulation of neurotrophic signaling pathways by polyphenols. Drug Des. Dev. Ther. 2016, 10, 23-42.

191. Wang, Y.; Gao, J.; Miao, Y.; Cui, Q.; Zhao, W.; Zhang, J.; Wang, H. Pinocembrin protects SH-SY5Y cells against MPP+-induced neurotoxicity through the mitochondrial apoptotic pathway. J. Mol. Neurosci. 2014, 53, 537-545. [CrossRef] [PubMed]

192. Gao, M.; Liu, R.; Zhu, S.Y.; Du, G.H. Acute neurovascular unit protective action of pinocembrin against permanent cerebral ischemia in rats. J. Asian Nat. Prod. Res. 2008, 10, 551-558. [CrossRef] [PubMed]

193. Liu, R.; Wu, C.X.; Zhou, D.; Yang, F.; Tian, S.; Zhang, L.; Zhang, T.T.; Du, G.H. Pinocembrin protects against $\beta$-amyloid-induced toxicity in neurons through inhibiting receptor for advanced glycation end products (RAGE)-independent signaling pathways and regulating mitochondrion-mediated apoptosis. BMC Med. 2012, 10, 105. [CrossRef] [PubMed]

194. Shi, L.L.; Chen, B.N.; Gao, M.; Zhang, H.A.; Li, Y.J.; Wang, L.; Du, G.H. The characteristics of therapeutic effect of pinocembrin in transient global brain ischemia/reperfusion rats. Life Sci. 2011, 88, 521-528. [CrossRef] [PubMed] 
195. Meng, F.; Liu, R.; Gao, M.; Wang, Y.; Yu, X.; Xuan, Z.; Sun, J.; Yang, F.; Wu, C.; Du, G. Pinocembrin attenuates blood-brain barrier injury induced by global cerebral ischemia-reperfusion in rats. Brain Res. 2011, 1391, 93-101. [CrossRef] [PubMed]

196. Jin, X.; Liu, Q.; Jia, L.; Li, M.; Wang, X. Pinocembrin attenuates 6-OHDA-induced neuronal cell death through Nrf2/ARE pathway in SH-SY5Y cells. Cell. Mol. Neurobiol. 2015, 35, 323-333. [CrossRef] [PubMed]

197. Heo, H.J.; Kim, D.O.; Shin, S.C.; Kim, M.J.; Kim, B.G.; Shin, D.H. Effect of antioxidant flavanone, naringenin, from Citrus junoson neuroprotection. J. Agric. Food Chem. 2004, 52, 1520-1525. [CrossRef] [PubMed]

198. Zbarsky, V.; Datla, K.P.; Parkar, S.; Rai, D.K.; Aruoma, O.I.; Dexter, D.T. Neuroprotective properties of the natural phenolic antioxidants curcumin and naringenin but not quercetin and fisetin in a 6-OHDA model of Parkinson's disease. Free Radic. Res. 2005, 39, 1119-1125. [CrossRef] [PubMed]

199. Lou, H.; Jing, X.; Wei, X.; Shi, H.; Ren, D.; Zhang, X. Naringenin protects against 6-OHDA-induced neurotoxicity via activation of the Nrf2/ARE signaling pathway. Neuropharmacology 2014, 79, 380-388. [CrossRef] [PubMed]

200. Linford, N.J.; Dorsa, D.M. $17 \beta$-Estradiol and the phytoestrogen genistein attenuate neuronal apoptosis induced by the endoplasmic reticulum calcium-ATPase inhibitor thapsigargin. Steroids 2002, 67, 1029-1040. [CrossRef]

201. Schreihofer, D.A.; Redmond, L. Soy phytoestrogens are neuroprotective against stroke-like injury in vitro. Neuroscience 2009, 158, 602-609. [CrossRef] [PubMed]

202. Wang, R.; Tu, J.; Zhang, Q.; Zhang, X.; Zhu, Y.; Ma, W.; Cheng, C.; Brann, D.W.; Yang, F. Genistein attenuates ischemic oxidative damage and behavioral deficits via eNOS/Nrf2/HO-1 signaling. Hippocampus 2013, 23, 634-647. [CrossRef] [PubMed]

203. Yu, L.; Wang, S.; Chen, X.; Yang, H.; Li, X.; Xu, Y.; Zhu, X. Orientin alleviates cognitive deficits and oxidative stress in Aß1-42-induced mouse model of Alzheimer's disease. Life Sci. 2015, 121, 104-109. [CrossRef] [PubMed]

204. Jing, X.; Shi, H.; Zhu, X.; Wei, X.; Ren, M.; Han, M.; Ren, D.; Lou, H. Eriodictyol Attenuates $\beta$-Amyloid 25-35 Peptide-Induced Oxidative Cell Death in Primary Cultured Neurons by Activation of Nrf2. Neurochem. Res. 2015, 40, 1463-1471. [CrossRef] [PubMed]

205. Kang, S.S.; Lee, J.Y.; Choi, Y.K.; Kim, G.S.; Han, B.H. Neuroprotective effects of flavones on hydrogen peroxide-induced apoptosis in SH-SY5Y neuroblostoma cells. Bioorg. Med. Chem. Lett. 2004, 14, 2261-2264. [CrossRef] [PubMed]

206. Cheng, H.Y.; Hsieh, M.T.; Tsai, F.S.; Wu, C.R.; Chiu, C.S.; Lee, M.M.; Xu, H.X.; Zhao, Z.Z.; Peng, W.H. Neuroprotective effect of luteolin on amyloid $\beta$ protein (25-35)-induced toxicity in cultured rat cortical neurons. Phytother. Res. 2010, 24 (Suppl. S1), S102-S108. [CrossRef] [PubMed]

207. Lin, C.W.; Wu, M.J.; Liu, I.Y.; Su, J.D.; Yen, J.H. Neurotrophic and cytoprotective action of luteolin in PC12 cells through ERK-dependent induction of Nrf2-driven HO-1 expression. J. Agric. Food Chem. 2010, 58, 4477-4486. [CrossRef] [PubMed]

208. Han, J.Y.; Ahn, S.Y.; Kim, C.S.; Yoo, S.K.; Kim, S.K.; Kim, H.C.; Hong, J.T.; Oh, K.W. Protection of apigenin against kainate-induced excitotoxicity by anti-oxidative effects. Biol. Pharm. Bull. 2012, 35, 1440-1446. [CrossRef] [PubMed]

209. Zhao, L.; Wang, J.L.; Liu, R.; Li, X.X.; Li, J.F.; Zhang, L. Neuroprotective, anti-amyloidogenic and neurotrophic effects of apigenin in an Alzheimer's disease mouse model. Molecules 2013, 18, 9949-9965. [CrossRef] [PubMed]

210. Tian, M.; Zeng, Y.; Hu, Y.; Yuan, X.; Liu, S.; Li, J.; Lu, P.; Sun, Y.; Gao, L.; Fu, D.; et al. 7,8-Dihydroxyflavone induces synapse expression of AMPA GluA1 and ameliorates cognitive and spine abnormalities in a mouse model of fragile $X$ syndrome. Neuropharmacology 2015, 89, 43-53. [CrossRef] [PubMed]

211. Gao, L.; Tian, M.; Zhao, H.Y.; Xu, Q.Q.; Huang, Y.M.; Si, Q.C.; Tian, Q.; Wu, Q.M.; Hu, X.M.; Sun, L.B.; McClintock, S.M.; Zeng, Y. TrkB activation by 7, 8-dihydroxyflavone increases synapse AMPA subunits and ameliorates spatial memory deficits in a mouse model of Alzheimer's disease. J. Neurochem. 2016, 136, 620-636. [CrossRef] [PubMed]

212. Jang, S.W.; Liu, X.; Yepes, M.; Shepherd, K.R.; Miller, G.W.; Liu, Y.; Wilson, W.D.; Xiao, G.; Blanchi, B.; Sun, Y.E.; et al. A selective TrkB agonist with potent neurotrophic activities by 7,8-dihydroxyflavone. Proc. Natl. Acad. Sci. USA 2010, 107, 2687-2692. [CrossRef] [PubMed] 
213. Qin, X.Y.; Cheng, Y.; Yu, L.C. Potential protection of curcumin against intracellular amyloid $\beta$-induced toxicity in cultured rat prefrontal cortical neurons. Neurosci. Lett. 2010, 480, 21-24. [CrossRef] [PubMed]

214. Begum, A.N.; Jones, M.R.; Lim, G.P.; Morihara, T.; Kim, P.; Heath, D.D.; Rock, C.L.; Pruitt, M.A.; Yang, F.; Hudspeth, B.; et al. Curcumin structure-function, bioavailability, and efficacy in models of neuroinflammation and Alzheimer's disease. J. Pharmacol. Exp. Ther. 2008, 326, 196-208. [CrossRef] [PubMed]

215. Zhang, L.; Fang, Y.; Xu, Y.; Lian, Y.; Xie, N.; Wu, T.; Zhang, H.; Sun, L.; Zhang, R.; Wang, Z. Curcumin improves amyloid $\beta$-peptide (1-42) induced spatial memory deficits through BDNF-ERK signaling pathway. PLOS ONE 2015, 10, e0131525. [CrossRef] [PubMed]

216. Pinkaew, D.; Changtam, C.; Tocharus, C.; Thummayot, S.; Suksamrarn, A.; Tocharus, J. $\mathrm{Di}-\mathrm{O}$-demethylcurcumin protects SK-N-SH cells against mitochondrial and endoplasmic reticulum-mediated apoptotic cell death induced by A $\beta 25-35$. Neurochem. Int. 2015, 80, 110-119. [CrossRef] [PubMed]

217. Yang, Y.; Shuaib, A.; Li, Q.; Siddiqui, M.M. Neuroprotection by delayed administration of topiramate in a rat model of middle cerebral artery embolization. Brain Res. 1998, 804, 169-176. [CrossRef]

218. Niebauer, M.; Gruenthal, M. Topiramate reduces neuronal injury after experimental status epilepticus. Brain Res. 1999, 837, 263-269. [CrossRef]

219. Mao, X.Y.; Cao, Y.G.; Ji, Z.; Zhou, H.H.; Liu, Z.Q.; Sun, H.L. Topiramate protects against glutamate excitotoxicity via activating BDNF/TrkB-dependent ERK pathway in rodent hippocampal neurons. Prog. Neuropsychopharmacol. Biol. Psychiatry 2015, 60, 11-17. [CrossRef] [PubMed]

220. Jeong, E.J.; Lee, K.Y.; Kim, S.H.; Sung, S.H.; Kim, Y.C. Cognitive-enhancing and antioxidant activities of iridoid glycosides from Scrophularia buergeriana in scopolamine-treated mice. Eur. J. Pharmacol. 2008, 588, 78-84. [CrossRef] [PubMed]

221. Li, J.; Ding, X.; Zhang, R.; Jiang, W.; Sun, X.; Xia, Z.; Wang, X.; Wu, E.; Zhang, Y.; Hu, Y. Harpagoside ameliorates the amyloid- $\beta$-induced cognitive impairment in rats via up-regulating BDNF expression and MAPK/PI3K pathways. Neuroscience 2015, 303, 103-114. [CrossRef] [PubMed]

222. Leon, R.; Wu, H.; Jin, Y.; Wei, J.; Buddhala, C.; Prentice, H.; Wu, J.Y. Protective function of taurine in glutamate-induced apoptosis in cultured neurons. J. Neurosci. Res. 2009, 87, 1185-1194. [CrossRef] [PubMed]

223. Jia, N.; Sun, Q.; Su, Q.; Dang, S.; Chen, G. Taurine promotes cognitive function in prenatally stressed juvenile rats via activating the Akt-CREB-PGC1 $\alpha$ pathway. Redox Biol. 2016, 10, 179-190. [CrossRef] [PubMed]

224. Cao, P.J.; Jin, Y.J.; Li, M.E.; Zhou, R.; Yang, M.Z. PGC-1 $\alpha$ may associated with the anti-obesity effect of taurine on rats induced by arcuate nucleus lesion. Nutr. Neurosci. 2016, 19, 86-93. [CrossRef] [PubMed]

225. Nagai, K.; Fukuno, S.; Oda, A.; Konishi, H. Protective effects of taurine on doxorubicin-induced acute hepatotoxicity through suppression of oxidative stress and apoptotic responses. Anticancer Drugs 2016, 27, 17-23. [CrossRef] [PubMed]

226. Scarpulla, R.C. Metabolic control of mitochondrial biogenesis through the PGC-1 family regulatory network. Biochim. Biophys. Acta 2011, 1813, 1269-1278. [CrossRef] [PubMed]

227. Packer, L.; Roy, S.; Sen, C.K. $\alpha$-Lipoic acid: A metabolic antioxidant and potential redox modulator of transcription. Adv. Pharmacol. 1997, 38, 79-101. [PubMed]

228. Koriyama, Y.; Nakayama, Y.; Matsugo, S.; Kato, S. Protective effect of lipoic acid against oxidative stress is mediated by Keap1/Nrf2-dependent heme oxygenase-1 induction in the RGC-5 cellline. Brain Res. 2013, 1499, 145-157. [CrossRef] [PubMed]

229. Li, X.H.; Li, C.Y.; Xiang, Z.G.; Zhong, F.; Chen, Z.Y.; Lu, J.M. Allicin can reduce neuronal death and ameliorate the spatial memory impairment in Alzheimer's disease models. Neurosciences 2010, 15, 237-243. [PubMed]

230. Zhu, Y.F.; Li, X.H.; Yuan, Z.P.; Li, C.Y.; Tian, R.B.; Jia, W.; Xiao, Z.P. Allicin improves endoplasmic reticulum stress-related cognitive deficits via PERK/Nrf2 antioxidative signaling pathway. Eur. J. Pharmacol. 2015, 762, 239-246. [CrossRef] [PubMed]

231. Petersen, R.C.; Thomas, R.G.; Grundman, M.; Bennett, D.; Doody, R.; Ferris, S.; Galasko, D.; Jin, S.; Kaye, J.; Levey, A.; et al. Vitamin E and donepezil for the treatment of mild cognitive impairment. N. Engl. J. Med. 2005, 352, 2379-2388. [CrossRef] [PubMed]

(C) 2017 by the authors. Licensee MDPI, Basel, Switzerland. This article is an open access article distributed under the terms and conditions of the Creative Commons Attribution (CC BY) license (http://creativecommons.org/licenses/by/4.0/). 